\title{
TSUNAMI HAZARD MAPS OF THE HOMER AND SELDOVIA AREAS, ALASKA
}

by

E.N. Suleimani, R.A. Combellick, D. Marriott, R.A. Hansen, A.J. Venturato, and J.C. Newman

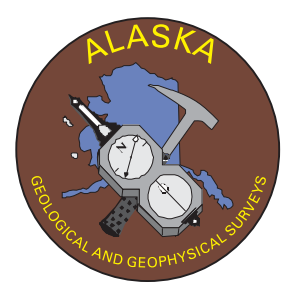

Published by

STATE OF ALASKA DEPARTMENT OF NATURAL RESOURCES

DIVISION OF GEOLOGICAL \& GEOPHYSICAL SURVEYS 
Report of Investigations 2005-2

\title{
TSUNAMI HAZARD MAPS OF THE HOMER AND SELDOVIA AREAS, ALASKA
}

\author{
by \\ E.N. Suleimani, R.A. Combellick, D. Marriott, \\ R.A. Hansen, A.J. Venturato, and J.C. Newman
}

2005

This DGGS Report of Investigations is a final report of scientific research. It has received technical review and may be cited as an agency publication. 


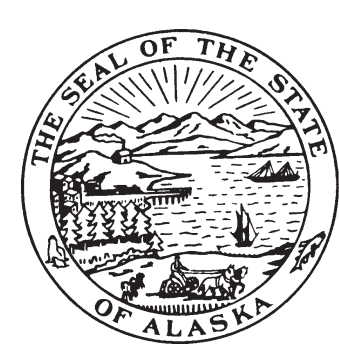

STATE OF ALASKA

Frank Murkowski, Governor

DEPARTMENT OF NATURAL RESOURCES

Mike Menge, Commissioner

\section{DIVISION OF GEOLOGICAL \& GEOPHYSICAL SURVEYS Robert F. Swenson, Acting State Geologist and Acting Director}

Division of Geological \& Geophysical Surveys publications can be inspected at the following locations. Address mail orders to the Fairbanks office.

$\begin{array}{ll}\begin{array}{l}\text { Alaska Division of Geological } \\ \text { \& Geophysical Surveys }\end{array} & \begin{array}{l}\text { University of Alaska Ancho } \\ \text { 3354 College Road }\end{array} \\ \begin{array}{l}\text { Anchorage, Alaska } 99508 \\ \text { Fairbanks, Alaska 99709-3707 }\end{array} & \\ \text { Elmer E. Rasmuson Library } & \text { Alaska Resource Library } \\ \text { University of Alaska Fairbanks } & \text { 3150 C Street, Suite 100 } \\ \text { Fairbanks, Alaska 99775-1005 } & \text { Anchorage, Alaska 99503 }\end{array}$

Alaska State Library

State Office Building, 8th Floor

333 Willoughby Avenue

Juneau, Alaska 99811-0571

This publication released by the Division of Geological \& Geophysical Surveys was produced and printed in Fairbanks, Alaska at a cost of $\$ 29$ per copy. Publication is required by Alaska Statute 41, "to determine the potential of Alaskan land for production of metals, minerals, fuels, and geothermal resources; the location and supplies of groundwater and construction materials; the potential geologic hazards to buildings, roads, bridges, and other installations and structures; and shall conduct such other surveys and investigations as will advance knowledge of the geology of Alaska.” 


\section{CONTENTS}

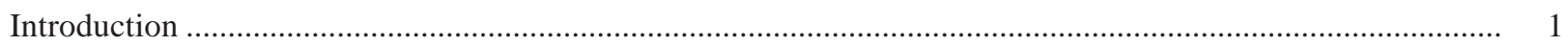

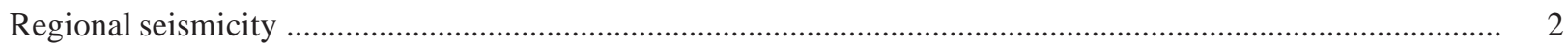

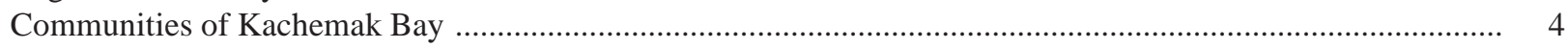

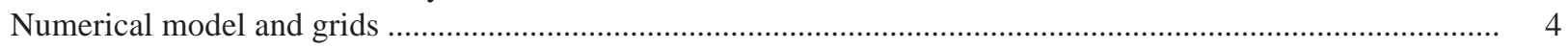

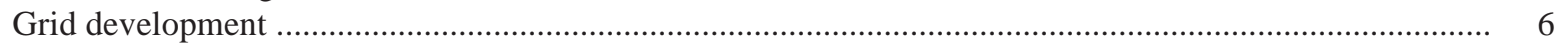

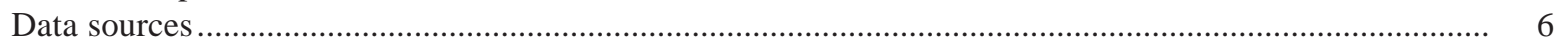

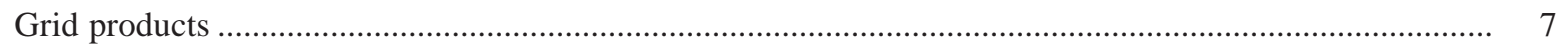

Source model for the 1964 tsunami .......................................................................................................... 7

Hypothetical tsunami scenarios .................................................................................................................. 7

Scenario 1. Repeat of 1964 event: 17 subfaults ...................................................................................... 9

Scenario 2. Hypothetical event: Border ranges fault rupture ...................................................................... 9

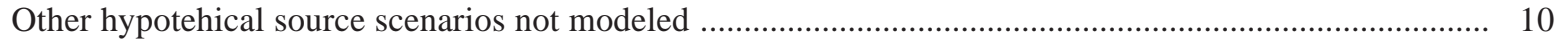

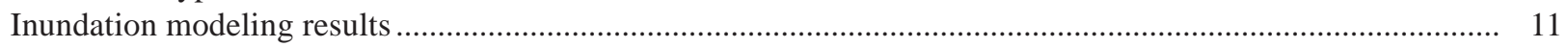

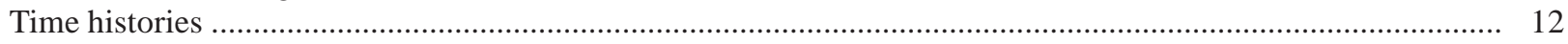

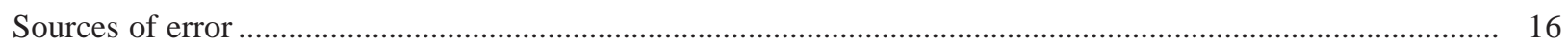

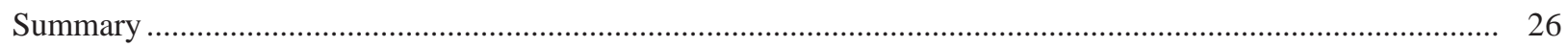

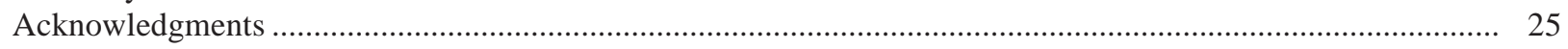

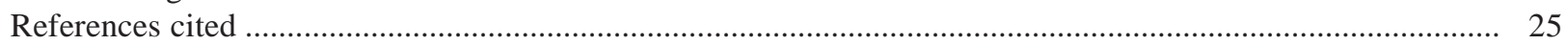

\section{TABLES}

Table 1. Data sources used for grid development ................................................................................... 6

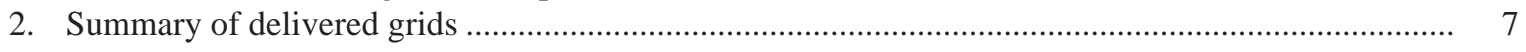

3. Subfault parameters for the Border Ranges fault scenario ................................................................ 10

\section{FIGURES}

Figure 1. Map of southcentral Alaska with major faults and rupture zone of the 1964 earthquake ................... 2

2. Map showing earthquakes in southcentral Alaska ............................................................................ 3

3. Map showing the grid area of 24-arc-second resolution .................................................................... 4

4. $\quad$ Map showing Homer 1-second grid area for inundation modeling ................................................... 5

5. Map showing Seldovia 1-second grid area for inundation modeling ……………............................. 5

6. Map showing slip distribution of the 1964 earthquake ............................................................................ 8

7. Map showing surface deformation of the 1964 earthquake ................................................................. 8

8. Map showing rupture area of the Border Ranges fault divided into three subfaults ............................ 9

9. Map showing surface deformation of the Border Ranges fault scenario ............................................. 10

10. Map showing depths and elevations for the Homer 1-second resolution grid .................................. 11

11. Map showing depths and elevations for the Seldovia 1-second resolution grid ................................ 12

12. Map showing depths of inundation near the head of Homer spit for scenario 1 ................................ 13

13. Map showing depths of inundation near the head of Homer spit for scenario 2 ................................ 13

14. Aerial photo showing tsunami inundation scenarios for Seldovia .................................................. 14

15. Aerial photo showing tsunami hazard map of Seldovia ...................................................................... 15

16. Graphs showing time histories of modeled tsunami waves at six locations offshore Homer Spit ...... 17

17. Graphs showing velocity time histories at six locations offshore Homer Spit .................................. 19

18. Graphs showing time histories of modeled tsunami waves at five locations offshore Seldovia ......... 21

19. Graphs showing velocity time histories at five locations offshore Seldovia ...................................... 23

\section{APPENDIX}

Vertical datum conversions for Homer and Seldovia, Alaska ....... 


\title{
TSUNAMI HAZARD MAPS OF THE HOMER AND SELDOVIA AREAS, ALASKA
}

\author{
by \\ E.N. Suleimani ${ }^{1}$, R.A. Combellick ${ }^{2}$, D. Marriott ${ }^{1}$, R.A. Hansen $^{1}$, A.J. Venturato ${ }^{3}$, and J.C. Newman ${ }^{3}$
}

\begin{abstract}
The purpose of this study is to evaluate a potential tsunami risk for communities of Homer and Seldovia in the Kachemak Bay area, Alaska. This report will provide guidance to the local emergency managers in tsunami hazard assessment. We used a numerical modeling method to estimate the extent of inundation due to tsunami waves generated by earthquake sources. Our tsunami scenarios included a repeat of the tsunami of the 1964 great Alaska earthquake, as well as a hypothetical tsunami wave generated by a local fault source. We didn't consider landslide-generated tsunamis in this study. Results of numerical modeling combined with historical observations in the region are intended to help local emergency services officials with evacuation planning and public education for reducing risk from future tsunamis.
\end{abstract}

\section{INTRODUCTION}

Alaska has the greatest earthquake and tsunami potential in the entire United States. Figure 1 shows one of the most seismically active regions of the state where the Pacific Plate is subducting under the North American Plate. This subduction zone, the Alaska-Aleutian megathrust zone, makes the adjacent coastal areas especially hazardous with regard to tsunami exposure. The coseismic crustal movements that characterize this area have a high potential for producing vertical sea floor displacements, which are highly tsunamigenic. Historic tsunamis that were generated by earthquakes on the Alaska-Aleutian subduction zone have resulted in widespread damage and loss of life along the Alaskan Pacific coast and other exposed locations around the Pacific Ocean. Large seismic events occurring in the vicinity of the Alaska Peninsula, Aleutian Islands, and Gulf of Alaska have a very high potential for generating both local and Pacific-wide tsunamis. Tsunamis originating in Alaska can travel across the Pacific and destroy coastal towns hours after they are generated. However, they are considered to be a near-field hazard for Alaska, and can reach Alaskan coastal communities within minutes after the earthquake. Therefore, saving lives and property depends on how well a community is prepared, which makes it essential to estimate the potential flooding area of the coastal zones in case of a local or distant tsunami.

To help mitigate the risk these earthquakes and tsunamis pose to Alaskan coastal communities, the Alaska Tsunami Mapping Team (ATMT) was created. It consists of Geophysical Institute (GI) of the University of Alaska Fairbanks and the State of Alaska Division of
Geological \& Geophysical Surveys (ADGGS). The ATMT participates in the National Tsunami Hazard Mitigation Program (NTHMP) by evaluating and mapping potential inundation of selected parts of Alaska coastlines using numerical modeling of tsunami wave dynamics. The communities are selected for inundation modeling in coordination with the Division of Homeland Security and Emergency Management (DHSEM) with consideration to location, infrastructure, availability and quality of bathymetric and topographic data, and community involvement.

Kachemak Bay, home to the communities of Homer and Seldovia, is one of the high-priority regions for Alaska inundation mapping. It has several communities with significant population and extensive fishing resources. Homer and Seldovia were chosen by DHSEM and Kenai Peninsula local government officials as preferred sites for runup modeling. Emergency managers need tsunami evacuation maps for these communities, showing the extent of inundation with respect to human and cultural features, and evacuation routes.

The production of tsunami evacuation maps consists of several stages. First, hypothetical tsunami scenarios are constructed based on the parameters of potential underwater earthquakes. Then, model simulations are performed for each of the earthquake source scenarios. The results are compared with any observations from historical tsunamis in the region, if such data exist. Finally, numerical results and historical observations are combined in order to develop a "worst case scenario for a tectonically generated tsunami” for every community on a map. The inundation line produced by this scenario

\footnotetext{
${ }_{1}^{1}$ Alaska Earthquake Information Center, Geophysical Institute, University of Alaska, P.O. Box 757320, Fairbanks, Alaska 99775-7320

${ }^{2}$ Alaska Division of Geological \& Geophysical Surveys, 3354 College Rd., Fairbanks, Alaska 99709-3707

${ }^{3}$ Pacific Marine Environmental Laboratory, National Oceanic \& Atmospheric Administration, 7600 Sand Point Way NE, Seattle, Washington 98125
} 


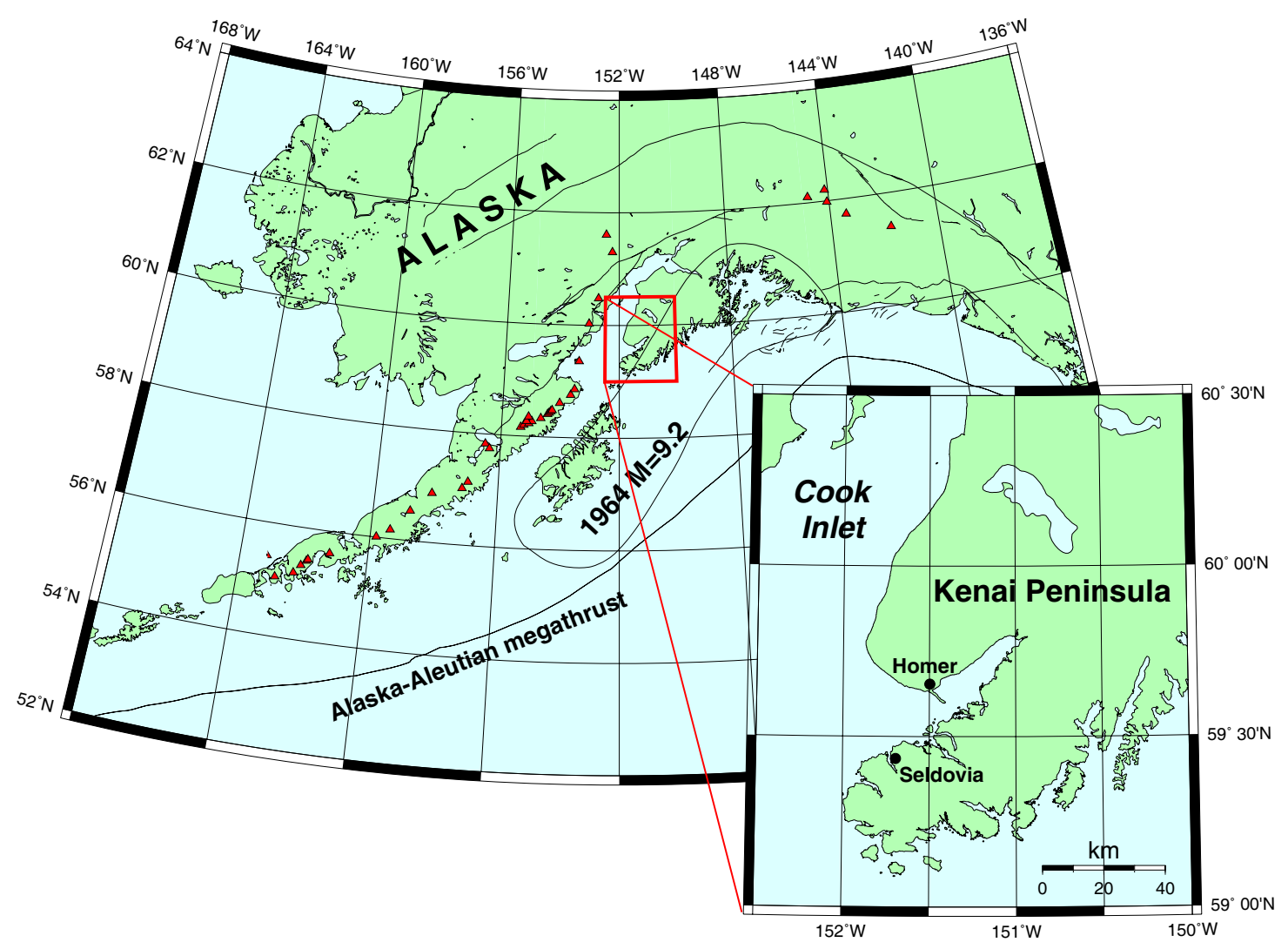

Figure 1. Map of southcentral Alaska with major faults and rupture zone of the 1964 earthquake (black lines). Red triangles indicate active volcanoes. Inset figure shows communities of Homer and Seldovia in Kachemak Bay.

becomes a basis for local tsunami hazard planning and construction of evacuation maps. Our analysis did not include waves produced from submarine landslides.

The tsunami hazard maps of Homer and Seldovia described in this report represent the results of continuous effort of state and federal agencies to produce inundation maps for many Alaskan coastal communities. The inundation lines calculated for two different tsunami scenarios are shown in sheet 1 for the city of Homer. Sheet 2 shows the extent of inundation in the same community resulting from the "worst case scenario," which is the maximum inundation of the modeled scenarios. Seldovia inundation maps are included as figures in this report.

In this report, we generally provide both metric and English units of measure. However, where we quote existing data, we report the data in the original units of measure without conversion. To convert kilometers to miles, multiply by 0.6214 .

\section{REGIONAL SEISMICITY}

Kachemak Bay is located in an area of very high seismic activity (fig. 2). The tectonics of the region is dominated by the convergence of the Pacific and North
American Plates, which interact along the Aleutian Megathrust (Page and others, 1991). The convergence rate is approximately $56 \mathrm{~mm} / \mathrm{yr}$ (2.2 in/yr) (DeMets and others, 1990). The Kenai Peninsula is located close to the northeast end of the Aleutian Megathrust, where the megathrust is strongly coupled and has a shallow dip angle of about 7 degrees. This zone has the potential to produce some of the largest earthquakes in the world, as demonstrated by the great Alaska earthquake of 1964 (moment magnitude 9.2). These plate motions also have the potential to drive significant seismicity within both the overriding plate and the subducting slab (Doser and Brown, 2001).

Freymueller and others (2000) used GPS measurements of the crustal motions to study the deformation of the region and model the plate interactions. They found that under the eastern portion of the Kenai Peninsula and in Prince William Sound, the plates are nearly completely locked, while under the western portion of the Kenai Peninsula the plates are freely slipping. This correlates with Doser and Brown's findings (2001) that the central and southern Kenai Peninsula have been seismically quiet at the $\mathrm{M}_{\mathrm{w}}>5$ level since the 1964 event, while the Prince William Sound area has continued to 
have seismic activity similar to that occurring before the 1964 earthquake.

Figure 2 plots seismicity in southcentral Alaska with locations taken from the Alaska Earthquake Information Center catalog. The events with the moment magnitude less than 6 are shown as small dots and color-coded according to depth, and the red box indicates the location of the region of interest. Previous to the installation of seismic network in Alaska in the early 1970s, only relatively larger events were reliably located $\left(M_{w} \approx 6\right)$. After installation of the network, events of much smaller sizes were regularly located. After the 1964 event the rate of seismic moment release was significantly reduced in the region surrounding Kachemak Bay (Doser and others, 2004). Figure 2 demonstrates this fact by showing earthquakes with $M_{w} \geq 6$ that occurred before and after the 1964 event as big circles, with symbol size proportional to the magnitude of the event. The main shock and aftershocks of the 1964 event are not included in this plot.

Combellick (1997) presented geologic evidence of prehistoric great earthquakes in the Cook Inlet region, where he estimates between six and nine 1964-style $\left(M_{w} \approx 9\right)$ earthquakes during the past 5,000 yr, with an average recurrence interval of 600 to $800 \mathrm{yr}$.

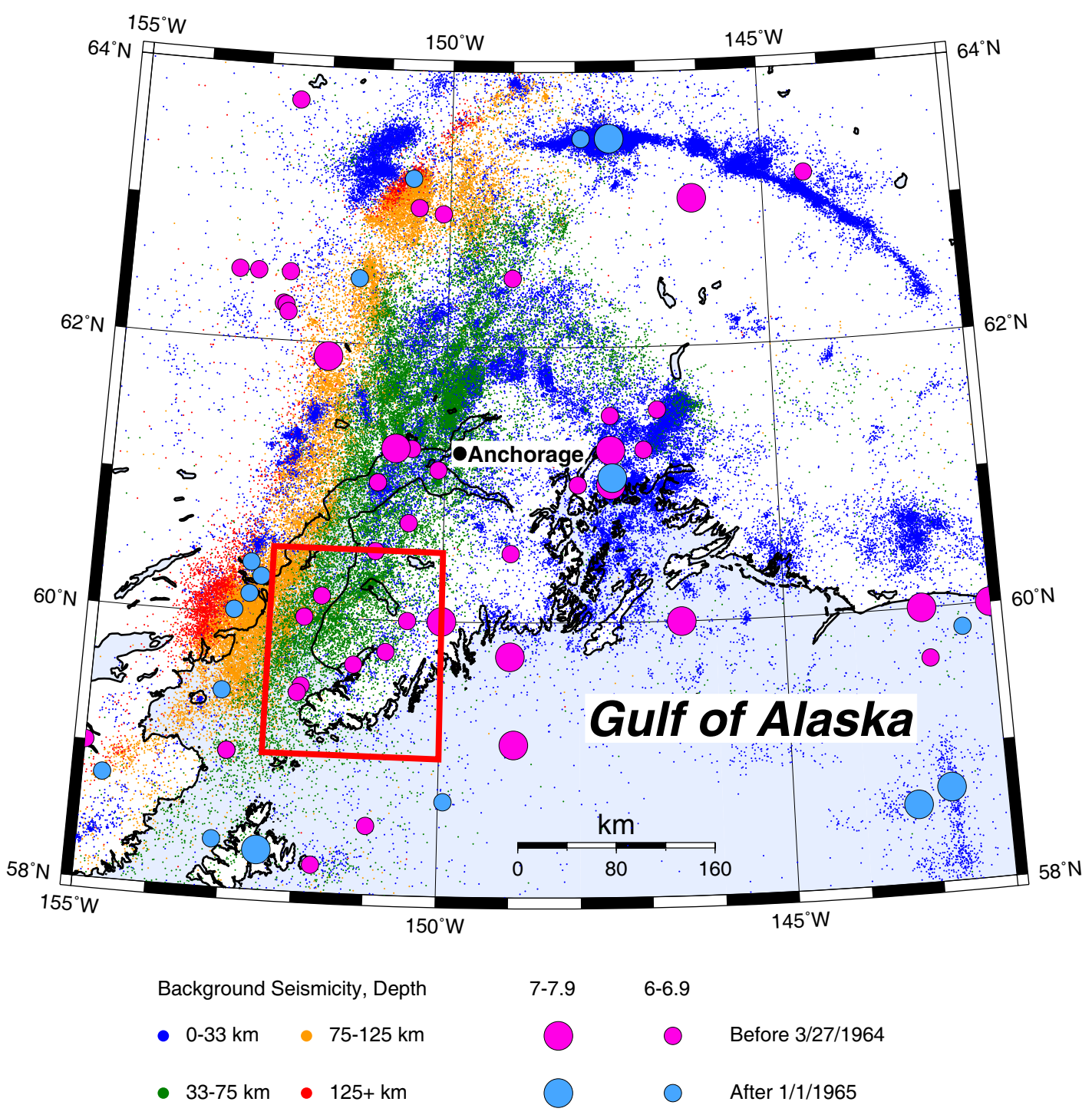

Figure 2. Earthquakes in southcentral Alaska, from the Alaska Earthquake Information Center catalog. The red rectangle is the same area as the inset in figure 1. Small dots correspond to earthquakes with magnitude 5.9 and smaller. Large circles show significant earthquakes (magnitude 6 and greater) before (purple) and after (light blue) the great Alaska earthquake of March 27, 1964. The main shock and aftershocks of this event are not included in the plot. 


\section{COMMUNITIES OF KACHEMAK BAY}

Kachemak Bay is located in the southeastern part of Cook Inlet (fig. 3). The Bay is very rich in natural resources. For decades, commercial fishing has been the major source of income for residents of Kachemak Bay. Tourism also plays a very important role in the local economy. The community of Homer and the rest of the Kachemak Bay area have been one of the earliest areas of southcentral Alaska to develop a significant visitor industry. Thousands of people come to sightsee, fish, hike, and view wildlife, mostly during the summer months. Homer (population approx. 4,000) is the largest of the Kachemak Bay communities. The Homer small boat harbor is home to more than 700 charter and commercial boat operations year round, growing to 1,500 in the summer months. Local, state, and federal government offices are located in downtown Homer, at elevations well above the reach of tsunamis. The Homer Spit is a narrow glacial feature extending approximately $7.2 \mathrm{~km}(4.5 \mathrm{mi})$ from the town of Homer into Kachemak Bay. The commercial and industrial center of the community is located on the Spit. It enjoys heavy summer recreational use and is especially vulnerable to large sea waves. Severe storms accompanied by high water levels and waves have occasionally overtopped the roadway on the Homer Spit, causing the road to close. Seldovia (population 300) is located $27 \mathrm{~km}(17 \mathrm{mi})$ across Kachemak Bay from Homer (fig. 1). Commercial fishing and shellfish processing are local economic activities. There are timber operations in Seldovia Bay and nearby Jakolof Bay, and tourism is increasing.

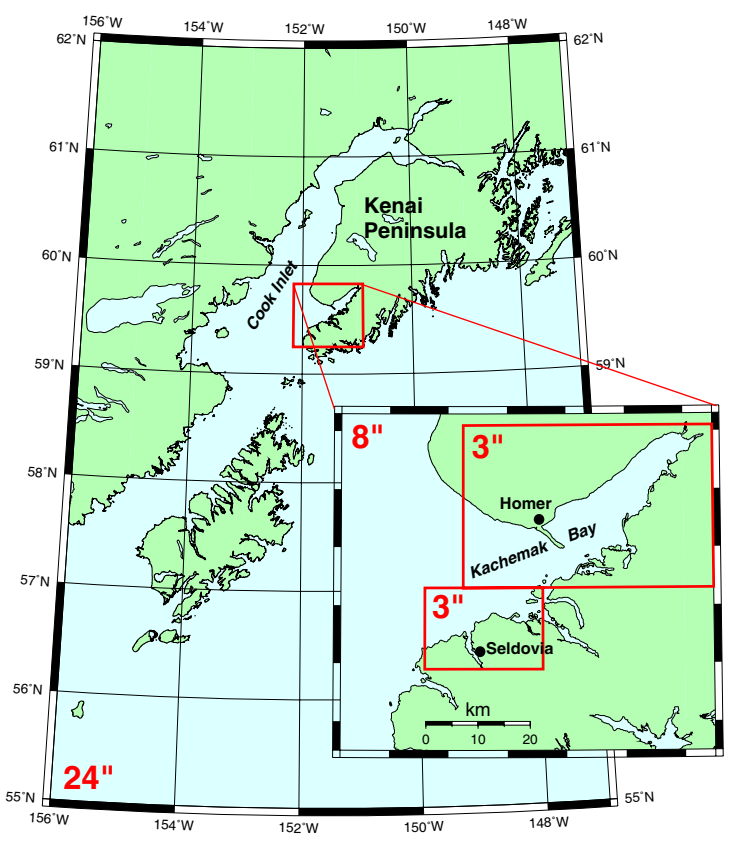

Effects of the Great Alaska Earthquake of March 27, 1964, on the communities of Homer and Seldovia included severe shaking, ground fissuring, landslides, submarine landslides, subsidence, and seismically induced waves (Waller, 1966). The damage was relatively light compared to other Alaskan communities. The primary effect on the Homer Spit was land subsidence that caused much of the spit to be submerged during the next high tide. The subsidence was partially tectonic, and partially due to compaction of unconsolidated gravel. Average subsidence along the spit was $5.3 \mathrm{ft}(1.6 \mathrm{~m})($ Waller, 1966). The area of greatest subsidence of about $10 \mathrm{ft}(3 \mathrm{~m})$ was at the end of the spit where a soil pile was formed by excavation of the harbor. Tectonic subsidence accounted for about $2 \mathrm{ft}(0.6 \mathrm{~m})$ of the total subsidence along the entire spit.

Several unusual sea waves were observed within minutes of the onset of shaking, from both the Kachemak Bay side and the Cook Inlet side of Homer Spit. These were probably from seiche action and small local submarine landslides. Two submarine landslides occurred at the end of Homer Spit (Waller, 1966). One of them destroyed the small-boat harbor breakwater. The second slide caused an area west of the Salty Dawg Saloon to collapse about $10 \mathrm{ft}(3 \mathrm{~m})$, with several buildings slumping into the collapse. The Seldovia area subsided with a vertical drop of $6 \mathrm{ft}(1.8 \mathrm{~m})$, which completely changed its waterfront. Long-term damage at Seldovia caused by subsidence was much greater than that caused by tsunami waves. At Homer, the destructive power of the tectonic tsunamis was limited due to the fact that the largest waves arrived at low tide, and a 20-ft (6-m) tidal freeboard protected the town (Waller, 1966).

In November 2001, site visits and exploratory meetings were conducted in Homer for the purpose of evaluating Kachemak Bay regional needs for tsunami inundation maps. This activity was a component of the NTHMP that is intended to provide assistance to coastal communities with tsunami hazard assessment. As a result, communities of Homer and Seldovia were selected for inundation modeling out of several Kachemak Bay communities.

\section{NUMERICAL MODEL AND GRIDS}

We calculate the extent of inundation caused by tsunami waves using numerical modeling of tsunami wave runup. The model is based on the vertically integrated nonlinear shallow water equations of motion and continuity with friction and Coriolis force (Murty, 1984). We

Figure 3. The grid area of 24-arc-second resolution. The red rectangle delineates the 8-second grid that covers Kachemak Bay. Inset figure shows two 3-second grids for Homer and Seldovia. 
apply a space-staggered grid, which requires either sea level or velocity as a boundary condition. The first order scheme is applied in time and the second order scheme is applied in space. Integration is performed along the north-south and west-east directions separately as described by Kowalik and Murty (1993).

In order to propagate the wave from a source to various coastal locations we use embedded grids, placing a large, coarse grid in deep water and coupling it with smaller, finer grids in shallow water areas. We use an interactive grid splicing, therefore the equations are solved on all grids at each time step, and the values along the grid boundaries are interpolated at the end of every time step (Troshina, 1996). The radiation condition is applied at the open (ocean) boundaries (Reid and Bodine, 1968). At the water-land boundary, the moving boundary condition is used in those grids that cover areas selected for inundation mapping (Kowalik and Murty, 1993). In all other grids, the velocity component normal to the coastline is assumed to be zero.

The region shown in figure 1 (Gulf of Alaska) is covered by the largest grid of 2-arc-minute resolution. We use four embedded grids in order to increase resolution from 2 arc minutes (2 $\mathrm{km} \mathrm{x}$ $3.7 \mathrm{~km}$ at $55^{\circ} \mathrm{N}$ latitude) in the Gulf of Alaska to 1 arc second (15.7 m x $30.8 \mathrm{~m}$ at $59^{\circ} 35^{\prime}$ latitude) in the two grids that cover the communities of Homer and Seldovia. The embedded grids are shown in figure 3 . The first grid of 24-second resolution covers the lower part of Cook Inlet and waters around Kodiak Island. The 8-second grid covers Kachemak Bay, and there are two 3-second grids that cover waters around Homer Spit and Seldovia Bay. Inside each of the 3-second grids we placed a 1-second resolution grid where runup calculations are performed. The 1-second grids for Homer and Seldovia are shown in figures 4 and 5, respectively. In these grids, the combined bathymetric and topographic data allow for application of the moving boundary condition as well as calculating the runup heights and extent of the inundation.
In the output of the numerical model, each of the grid points has either a value of 0 where no inundation occurs, or 1 if seawater reaches the grid point at any time during any tsunami wave. The inundation line approximately follows the 0.5 contour between these 0 and 1 point values but was adjusted visually to accommodate obstacles or local variations in topography that are not represented by the DEM. Although the location of the inundation line has an accuracy of approximately plus or minus $25 \mathrm{~m}$ horizontally relative to the grid spacing, the true location accuracy is unknown because the lines are the result of a complex modeling process whose accuracy depends on many factors. These factors include correctness of the earthquake source model, accuracy of the bathymetric and topographic data, and the adequacy of the numerical model in representing the

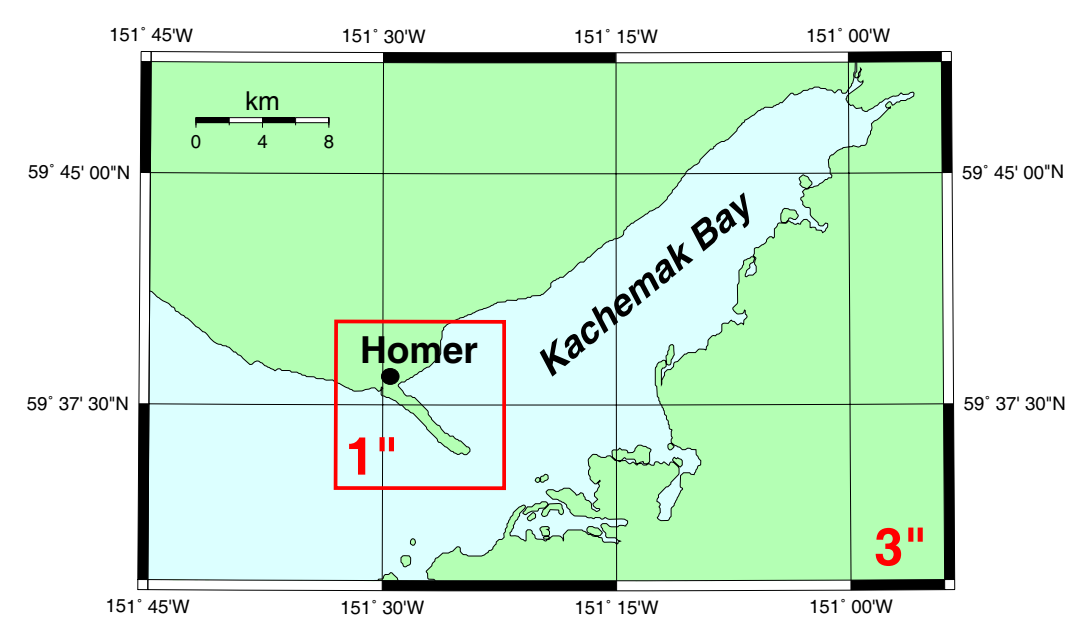

Figure 4. Homer 1-second grid area for inundation modeling

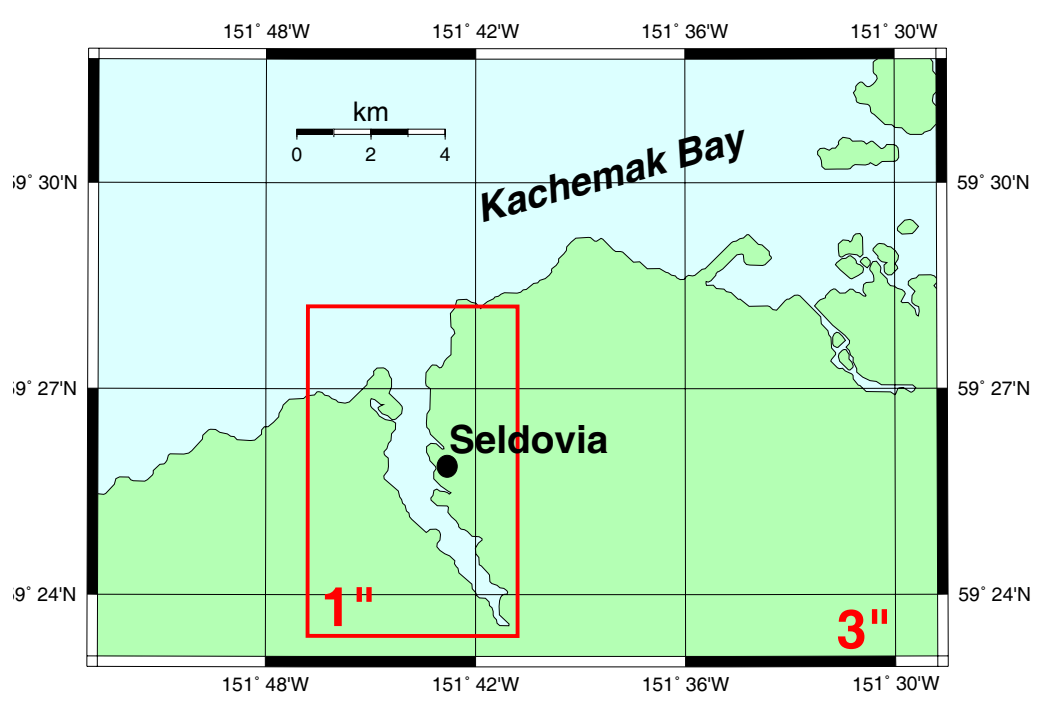

Figure 5. Seldovia 1-second grid area for inundation modeling. 
generation, propagation, and run-up of tsunami waves. We did not attempt to adjust the modeled inundation limits to account for these uncertainty factors.

There are several limitations of the model. It does not take into account the periodical change of sea level due to tides. We conducted all model runs using bathymetric data that correspond to Mean Higher High Water (MHHW). For the generation mechanism, we model only earthquakes as potential sources of tsunami waves. Landslide wave sources are not considered within the scope of this generation model.

\section{GRID DEVELOPMENT}

The Center for Tsunami Inundation Mapping Efforts (TIME), National Oceanic \& Atmospheric Administration, created seven data grids (figs. 3-5) for the Kachemak Bay region using the best available bathymetry and topography. TIME developed data grids using the following five-step process of (1) data assessment, (2) data collection, (3) grid computation, (4) grid assessment and (5) product delivery. The best available bathymetric and topographic data, including LIDAR, were obtained from government and private industries, as well as from local sources. These data were converted into a usable format and then analyzed for quality using ArcView and ArcInfo software packages. Data sources were selected based on several factors, including availability, cost, resolution, and accuracy. Refer to the Data Sources section for a list of the selected sources used in the data grids. The data were converted to meet the following parameters requested by ATMT:

- Coordinate System: Geographic

- Horizontal Datum: North American Datum 1927 (NAD27)

- Horizontal Units: decimal degrees

- Vertical Datum: Mean Higher High Water (MHHW)

- Vertical Units: meters
Refer to Appendix I for a description of vertical datum conversions. Data conversion and quality analysis were conducted using ESRI ArcView 3.2 and ArcInfo 8.0.2. Some datasets were digitized from GeoTiff images or scanned photos. Bathymetric and topographic grids were created using various ArcInfo scripts. For high-resolution grids, bathymetric and topographic grids were merged using the coastline as the zero contour (bathymetric values are negative; topographic values are positive). Low-resolution grids contained only bathymetric values; null data points were assigned a value of -9999. The metadata report delivered by TIME for each grid provides details of the grid computation process.

Each grid went through two quality control checks. TIME made comparisons between the original datasets and the grid. The nested grids were also compared to each other to verify continuity and accuracy. Datums were verified and blunders were removed. The preliminary grids were distributed to ATMT for a second quality analysis. ATMT reviewed each grid and TIME made modifications based on their analyses and other modeler requests.

\section{DATA SOURCES}

The final data sources used for the grids are described in table $1 .{ }^{4}$ Many data sources were in different formats, which introduces a small conversion error. The vertical accuracy of the data is based on the root mean square error: approximately 5 percent of depth for bathymetry and one-half the contour interval for topography. The metadata report delivered with each grid contains accuracy statistics.

\footnotetext{
${ }^{4}$ Note: New data sources were added to improve the grids over the grid development period. The data sources listed in table 1 represent the sources used in the final products. Refer to the metadata reports of each grid for more information about previous sources and their replacements.
}

Table 1. Data sources used for grid development

\begin{tabular}{|c|c|c|c|}
\hline Media Source & Dataset & Resolution & Description \\
\hline $\begin{array}{l}\text { National Geodetic } \\
\text { Data Center }\end{array}$ & $\begin{array}{l}\text { Hydrographic surveys, } \\
\text { marine tracklines }\end{array}$ & 10-500 meters & Bathymetric data \\
\hline $\begin{array}{l}\text { U.S. Geological } \\
\text { Survey (USGS) }\end{array}$ & $\begin{array}{l}\text { Digital raster graphics, } \\
\text { digital elevation models }\end{array}$ & $\begin{array}{l}\text { 10- and } 20 \text {-meter } \\
\text { contours }\end{array}$ & $\begin{array}{l}\text { 1:24,000 topographic contours } \\
\text { digitized from raster graphics }\end{array}$ \\
\hline $\begin{array}{l}\text { U.S. Army Corps } \\
\text { of Engineers }\end{array}$ & Hydrographic surveys & 10-30 meters & Bathymetric and topographic data \\
\hline $\begin{array}{l}\text { Walker and } \\
\text { Associates, Inc. }\end{array}$ & Analog photogrammetry & 2-foot contours & $\begin{array}{l}\text { Topographic data digitized from } \\
62 \text { images for Homer }\end{array}$ \\
\hline Aeromap, U.S. & LIDAR data & 4 meters & Topographic data for Homer \\
\hline
\end{tabular}




\section{GRID PRODUCTS}

Seven grids were delivered to ATMT. Each grid is described in table 2. All grids were delivered in xyz and ArcInfo exchange formats.

\section{SOURCE MODEL FOR THE 1964 TSUNAMI}

We initiated this project with the modeling of the Alaska 1964 tsunami because this event is probably the worst-case scenario of an earthquake-generated tsunami for Kachemak Bay communities. The 1964 Prince William Sound earthquake generated one of the most destructive tsunamis observed in Alaska and the west coast of the U.S. and Canada. This major tectonic tsunami was generated in the trench and upper plate fold and thrust belt area of the subduction zone (Plafker and others, 2000) and affected many communities in Alaska. The 1964 tsunami was studied in depth by several investigators (e.g. Kachadoorian and Plafker, 1967; Wilson and Torum, 1968), and their observed inundation patterns are available for calibration of the model. We use output of a submarine seismic source model as an initial condition for ocean surface displacement that then propagates away from the source. The amplitude of this initial disturbance is one of the major factors that affect the resulting runup amplitudes along the shoreline. Here we use an algorithm developed by Okada (1985) to calculate the distribution of coseismic uplift and subsidence resulting from the motion of the buried fault. The fault parameters that are required to compute the deformation of the ocean bottom are location of the epicenter, area of the fault, dip, rake, strike, and amount of slip on the fault. However, the rupture area of the 1964 earthquake was too large to be adequately described by a simple one-fault model. It was demonstrated by Christensen and Beck (1994) that there were two areas of high moment release, representing the two major asperities of the 1964 rupture zone: the Prince William Sound asperity and the Kodiak Island asperity. A detailed analysis of the 1964 rupture zone was presented by Johnson and others (1996) through joint inversion of the tsunami waveforms and geodetic data. These authors derived a detailed slip distribution for the 1964 earthquake, which is shown in figure 6.

To construct a source function for the 1964 event, we used the fault dislocation model developed by Johnson and others (1996), which has eight subfaults representing the Kodiak asperity, and nine subfaults in the Prince William Sound asperity. The authors didn't include the Patton Bay fault on Montague Island in the source mosaic, because the contribution of this fault to the tsunami waveforms was negligible. However, they removed the effect of this fault by subtracting the deformation due to the fault from all geodetic observations. We used the equations of Okada (1985) to calculate the distribution of coseismic uplift and subsidence resulting from the given slip distribution (fig. 7). Then, the derived surface deformation was used as the initial condition for tsunami propagation. During a model run, the initial topography was modified to account for residual seismic deformation of land due to the earthquake.

\section{HYPOTHETICAL TSUNAMI SCENARIOS}

We considered two hypothetical earthquake scenarios as potential sources of tsunami waves that can affect the Kachemak Bay communities. These scenarios represent both distant and local sources, and we model them using

Table 2. Summary of delivered grids

\begin{tabular}{|c|c|c|c|c|}
\hline Region & Name & Resolution & Extents & Delivery Date \\
\hline Southcentral Alaska & bathy2min & 2 arc-minutes & $\begin{array}{l}\text { SW: }-169.000000,52.000000 \\
\text { NE: }-140.000000,62.000000\end{array}$ & 01/16/2002 \\
\hline Cook Inlet & bathy24sec & 24 arc-seconds & $\begin{array}{l}\text { SW: }-156.000000,55.000000 \\
\text { NE: }-147.000000,62.000000\end{array}$ & 01/16/2002 \\
\hline Kachemak Bay & homer8sec & 8 arc-seconds & $\begin{array}{l}\text { SW: }-152.166667,59.253333 \\
\text { NE: }-150.906667,59.793333\end{array}$ & 01/16/2002 \\
\hline $\begin{array}{l}\text { Homer and } \\
\text { surroundings }\end{array}$ & homer3sec & 2.66 arc-seconds & $\begin{array}{l}\text { SW: }-151.751111,59.533333 \\
\text { NE: }-150.907407,59.792593\end{array}$ & 03/25/2002 \\
\hline $\begin{array}{l}\text { Seldovia and } \\
\text { surroundings }\end{array}$ & seld3sec & 2.66 arc-seconds & $\begin{array}{l}\text { SW: }-151.882222,59.391111 \\
\text { NE: }-151.475556,59.533333\end{array}$ & 03/07/2002 \\
\hline Homer & homer1sec & 0.88 arc-seconds & $\begin{array}{l}\text { SW: }-151.558518,59.583703 \\
\text { NE: }-151.366667,59.667407\end{array}$ & $12 / 18 / 2002$ \\
\hline Seldovia & seld1sec & 0.88 arc-seconds & $\begin{array}{l}\text { SW: }-151.782222,59.391852 \\
\text { NE: }-151.683704,59.474815\end{array}$ & 07/30/2002 \\
\hline
\end{tabular}




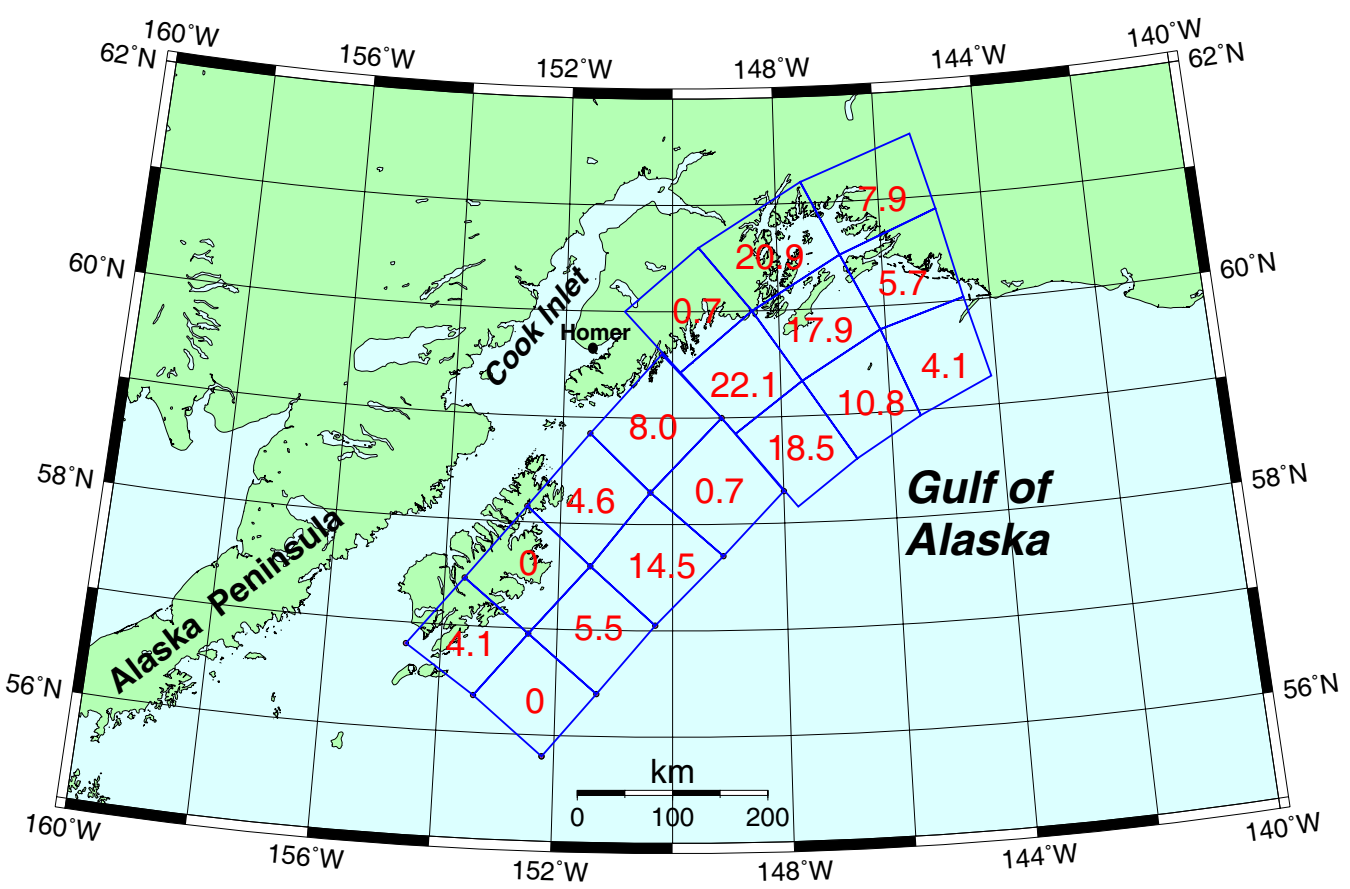

Figure 6. Slip distribution of the 1964 earthquake, from Johnson and others (1996). Numbers represent slip in meters on each subfault.

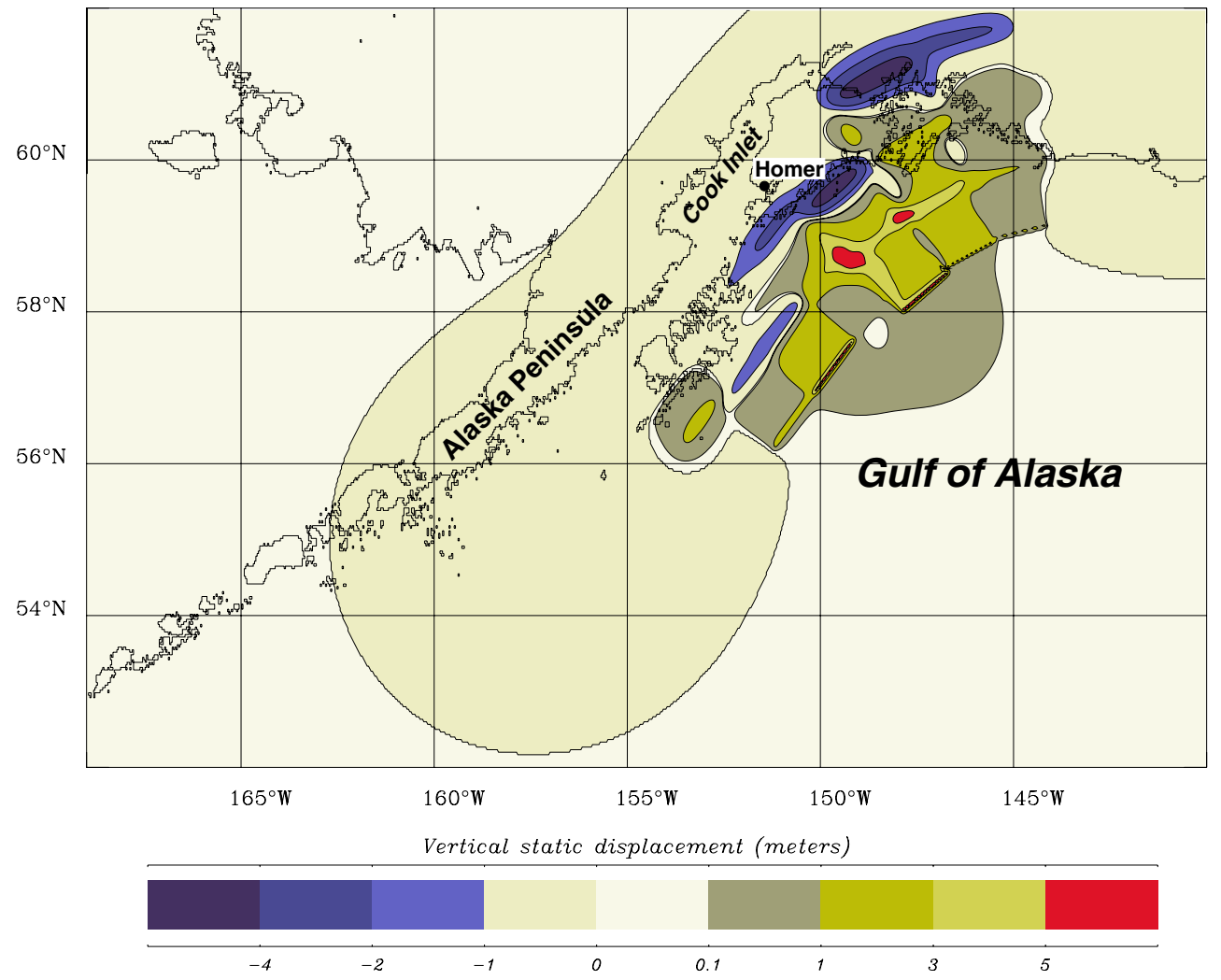

Figure 7. Surface deformation of the 1964 earthquake, calculated from the slip distribution given in figure 6. 
the multiple fault approach. There are two tsunami inundation limits on sheet 1 and in figure 14 that correspond to the tsunami scenarios described below.

\section{SCENARIO 1. REPEAT OF 1964 EVENT: 17 SUBFAULTS}

We modeled the 1964 tsunami wave using the source function described above. It consists of 17 subfaults, each having its own parameters (fig 6.). We assume that the initial displacement of the ocean surface from the equilibrium position is equal to vertical displacement of the ocean floor due to the earthquake rupture process. The model doesn't take into account the propagation of the moving rupture along the fault. We assume here that the bottom movement was instantaneous. Then, the model propagates this initial displacement from the source to coastal locations through the set of embedded grids of increasing resolution.

We tested this source function by modeling the 1964 tsunami inundation in the Kodiak Island communities. The results are described in Suleimani and others (2002). The comparison analysis of two different source models for the 1964 tsunami has shown that the wave generated by the complex source model with detailed slip distribution produces the inundation zone closest to that observed in 1964. Paleoseismic evidence indicates that 1964-style $\left(M_{w} \approx 9\right)$ events have an average recurrence interval of 600-800 yr in the Cook Inlet region (Combellick, 1997).

\section{SCENARIO 2. HYPOTHETICAL EVENT: BORDER RANGES FAULT RUPTURE}

This is a hypothetical earthquake that ruptures the section of the Border Ranges fault that crosses Kachemak Bay to the southwest of Homer (Bradley and others, 1999; Haeussler and Saltus, in review). The Border Ranges fault is a major fault of southern Alaska. It extends eastward from Kodiak Island to the St. Elias Mountains (MacKevett and Plafker, 1974). It defines the western front of the Kenai Mountains where they rise more than $1,300 \mathrm{~m}$. The hypothetical earthquake with moment magnitude of 7.5 was modeled using three subfaults (fig. 8); parameters are given in table 3 . The resulting surface deformation (fig. 9) was computed using the Okada (1985) algorithm. This event has a very low probability of occurrence; there is no historic evidence of earthquakes on the Border Ranges fault, and no geologic evidence of activity since Tertiary time.

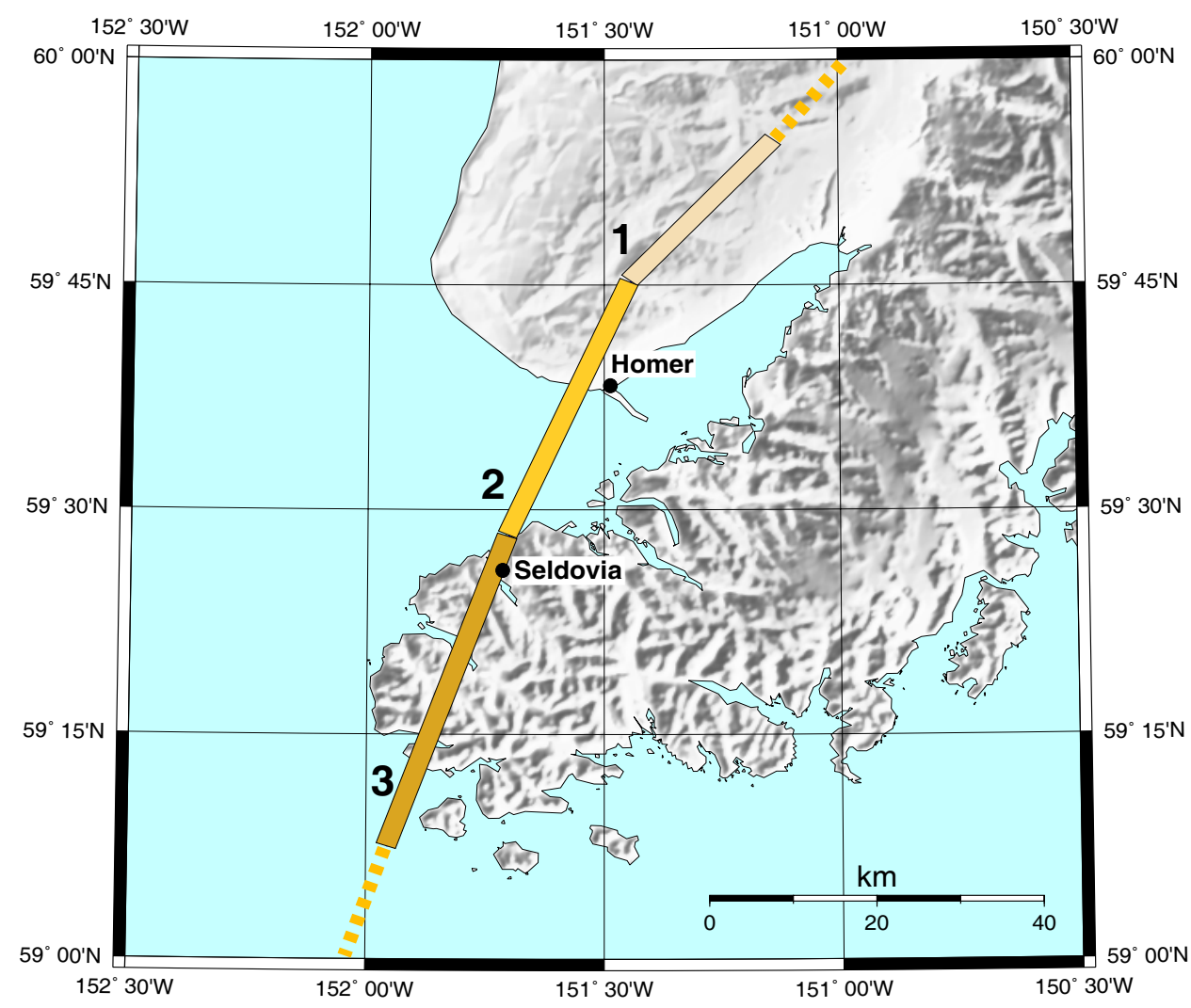

Figure 8. Rupture area of the Border Ranges fault divided into three subfaults. Parameters of the subfaults are presented in table 3. 


\section{OTHER HYPOTHETICAL SOURCE SCENARIOS NOT MODELED}

We have not modeled as part of this study the inundation by waves that might be generated by local submarine or subaerial landslides, nor have we modeled inundation from a debris avalanche generated by eruption of nearby Augustine Volcano, an island in Cook Inlet. In Troshina's (1996) study of tsunami waves generated by the 1883 eruption of Augustine Volcano, results of runup computations at English Bay (Nanwalek) confirm the historic observations, suggesting that the numerical model described the runup process adequately. Additionally, she showed that risk for Homer Spit from a volcanic tsunami is strongly determined by the landslide volume, the speed of the slide when it enters the water, and the direction of the slide motion. All these parameters are unknown at this time, making it difficult to realistically estimate the volcanigenic tsunami hazard. The potential hazard from volcanigenic tsunamis from Augustine Volcano was questioned by Waythomas (2000). He concluded that only a very large, rapidly moving debris avalanche that occurs at high tide could generate a potentially damaging wave. According to Waythomas, the lack of geologic evidence of tsunamis from two known large debris avalanches during the past 500 years suggests that the hazard from such events is low.

Table 3. Subfault parameters for the Border Ranges fault scenario. Displacement is up on the east side (normal).

\begin{tabular}{lcccccc}
\hline & Length, km & Width, $\mathbf{k m}$ & Strike, degrees & Dip, degrees & Rake, degrees & Slip, m \\
Subfault 1 & 25.28 & 20 & 223.8 & 80 west & -90 & 3 \\
Subfault 2 & 33.78 & 20 & 204.5 & 80 west & -90 & 3 \\
Subfault 3 & 41 & 20 & 201 & 80 west & -90 & 3 \\
\hline
\end{tabular}

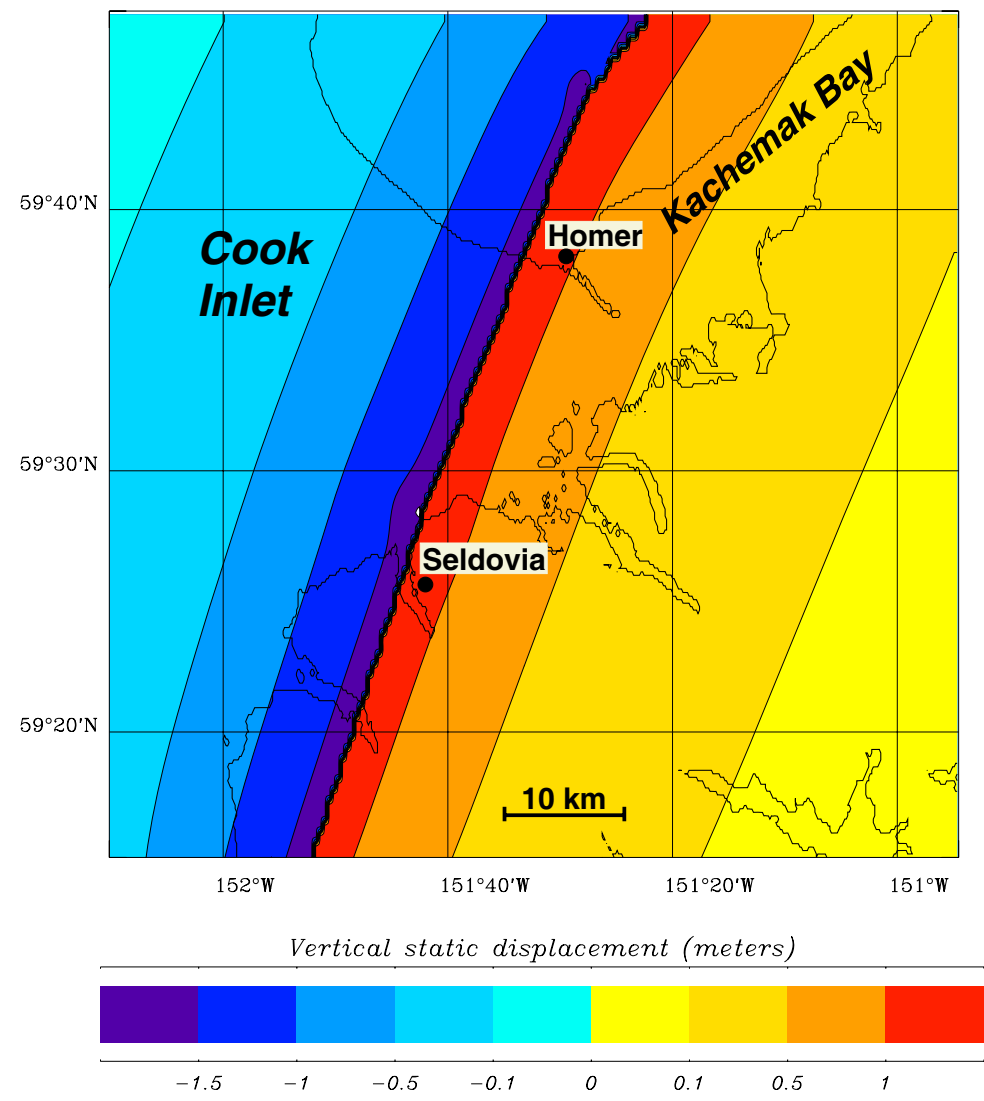

Figure 9. Surface deformation of the Border Ranges fault scenario, calculated from the slip distribution given in table 3 . 


\section{INUNDATION MODELING RESULTS}

We performed numerical calculations for the two scenarios described above. In every case, the initial water disturbance propagated through the set of embedded grids of increasing resolution. In the two final grids of $15.7 \mathrm{~m}$ x $30.8 \mathrm{~m}$ resolution, where bathymetric and topographic data are combined in a continuous data set, we computed the extent of inundation using the moving boundary condition. The combined bathymetry and topography data sets for Homer and Seldovia runup grids are shown in figures 10 and 11, respectively. The Homer grid has larger area at lower elevations compared to the Seldovia grid, where the slopes are relatively steep. Homer Spit, the low-lying, mostly submerged glacial moraine extending approximately $7.2 \mathrm{~km}$ (4.5 mi) from the town of Homer into Kachemak Bay, is especially vulnerable to large sea waves. In 1964, the entire spit subsided an average of $5.3 \mathrm{ft}(1.6 \mathrm{~m})$. Part of the subsidence was tectonic, and part was due to compaction of the unconsolidated gravel (Waller, 1966). We accounted for tectonic subsidence in the tsunami model by calculating the tectonic deformation patterns shown in Figures 7 and 9 for the high- resolution grid that includes Homer Spit. To take into account the part of the subsidence due to compaction, we introduced additional subsidence in the model along the Homer Spit by increasing subsidence linearly from zero at the head of the spit to $6 \mathrm{ft}$ $(1.8 \mathrm{~m})$ at the end of the spit.

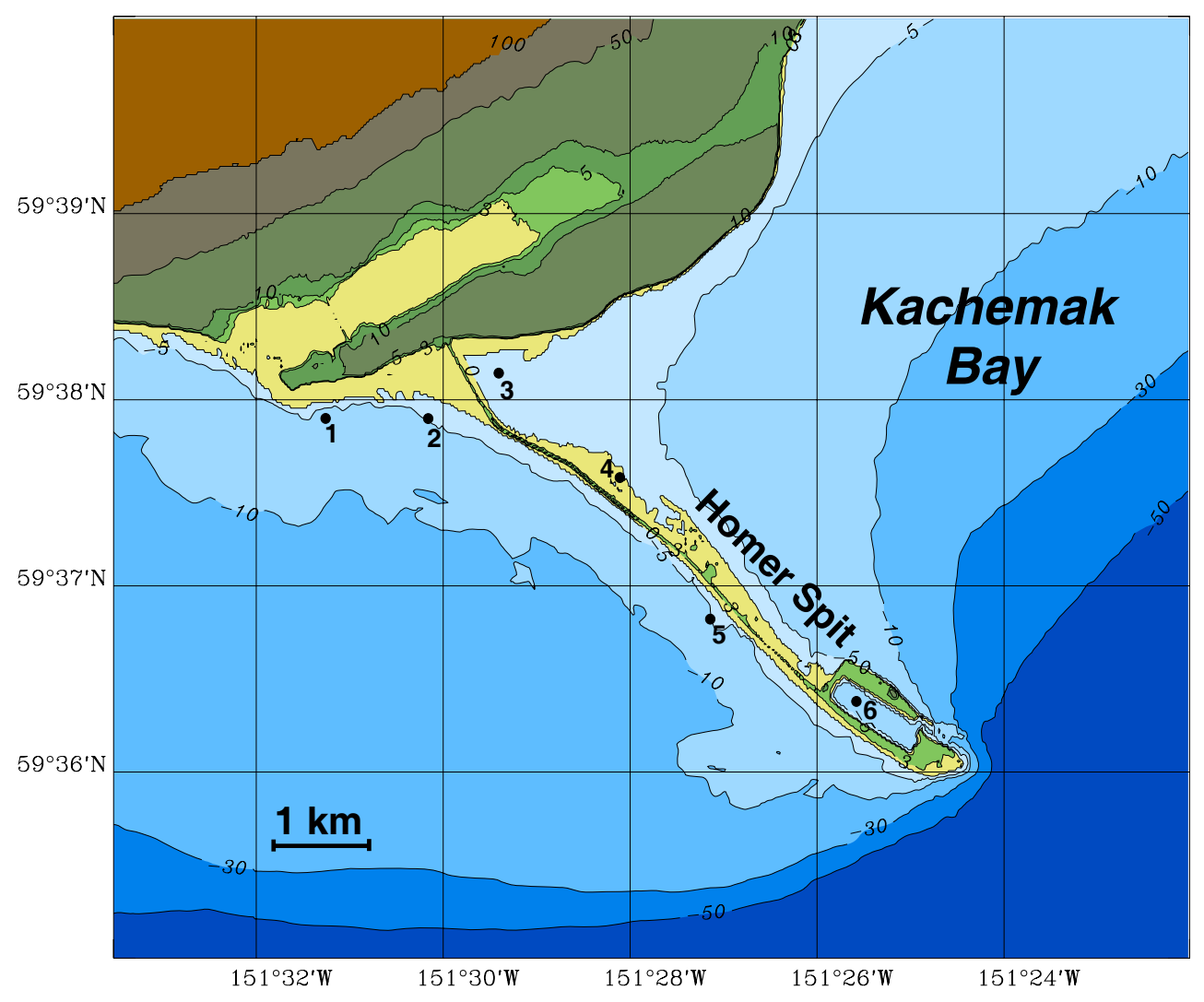

Bathymetry and topography (meters)

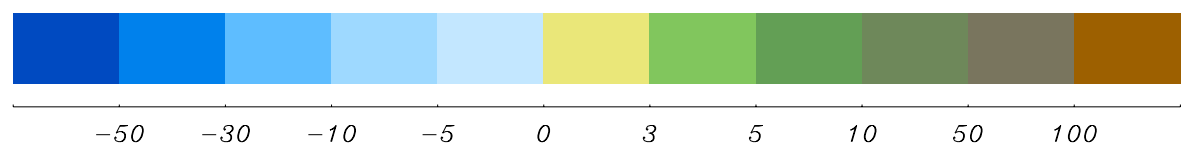

Figure 10. Depths and elevations for the Homer 1-second resolution grid. Depths are negative, land elevations are positive.

Points 1-6 indicate locations of time-history measurements shown in figures 16 and 17. 
The numerical modeling results for the Homer grid show that the two tsunami scenarios produce, on average, comparable inundation. In the marsh west of Beluga Lake, the inundation zone due to the Border Ranges fault scenario is much smaller than the inundation zone due to the 1964 scenario (map sheet 1). It is explained by the Border Ranges fault orientation with respect to this area. The wetlands are located in the region of maximum vertical displacement due to the Border Ranges fault rupture (fig. 9), and the same area has subsided according to the 1964 earthquake scenario surface deformation pattern (fig. 7). The maximum depths of inundation on dry land are shown in figures 12 and 13 for scenarios 1 and 2, respectively. At each grid point that corresponds to initially dry land, the depth of inundation is computed at every time step during the tsunami propagation time interval (10 hours), and the maximum value is kept. Depths of inundation on dry land are greater for the Border Ranges fault scenario, because the earthquake source is very close and there was not enough time for wave energy to dissipate.

The inundation at Seldovia is not substantial for both scenarios. The low-lying areas to the west from Trena Lake, the tip of the Watch Point, and sparse locations along Seldovia slough are the only places inundated as a result of the 1964 scenario tsunami wave (fig. 14). For the Border Ranges fault scenario, there is an additional flooded area at Watch Point with depths of inundation less than $2 \mathrm{~m}$. For these reasons we did not produce maps of inundation depths for Seldovia. Figure 15 shows the maximum worstcase inundation from both modeled scenarios at Seldovia.

The results of the inundation modeling imply that the local offshore earthquake of a smaller magnitude can generate a wave comparable to that produced by a great megathrust earthquake.

\section{TIME HISTORIES}

In order to provide more accurate assessment of tsunami hazard for any particular community, we have supplemented the inundation maps with information about the time history of the wave action in the region.

The time of arrival of the first wave, the wave with the maximum amplitude, and duration of the wave action are important factors that have to be considered by emergency managers during evacuation planning. We computed time histories of tsunami waves at six locations in the Homer grid and at five locations in the Seldovia grid for both tsunami scenarios. These locations are shown in figure 10 and on sheet 1 for Homer, and in figure 14 for Seldovia. The zero time corresponds to the epicenter origin time, and the zero water level 


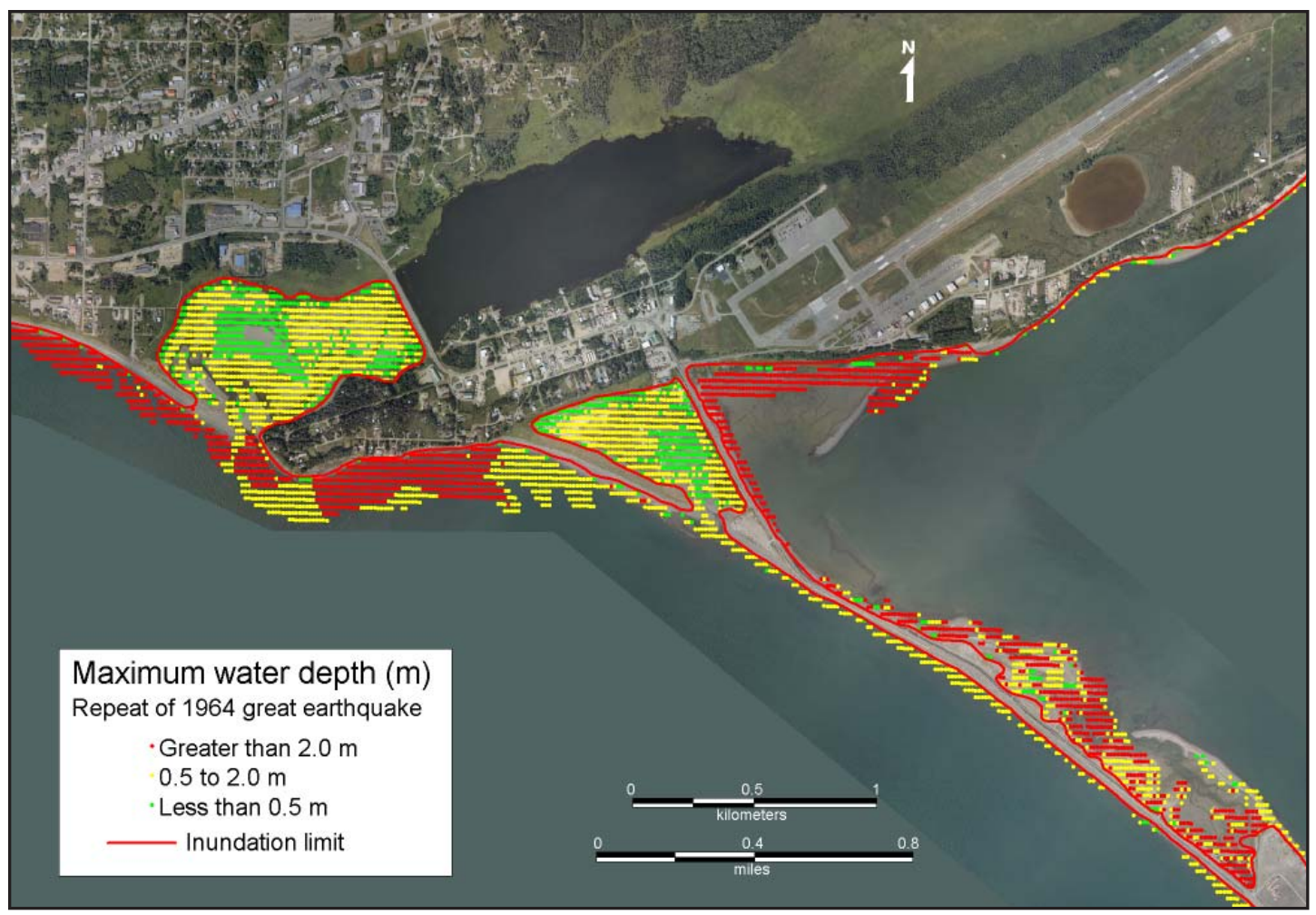

Figure 12. Depths of inundation near the head of Homer spit for scenario 1.

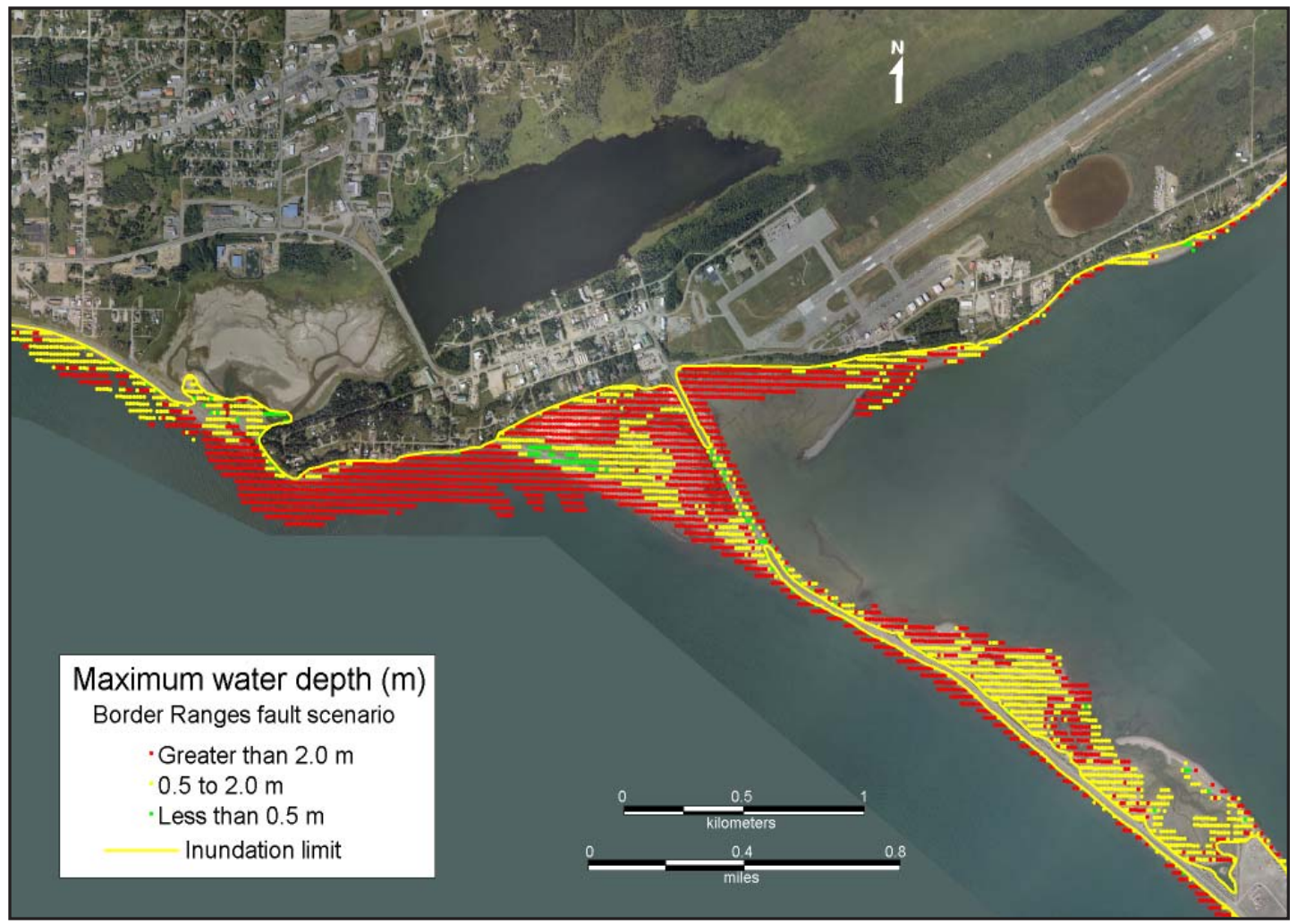

Figure 13. Depths of inundation near the head of Homer spit for scenario 2. 


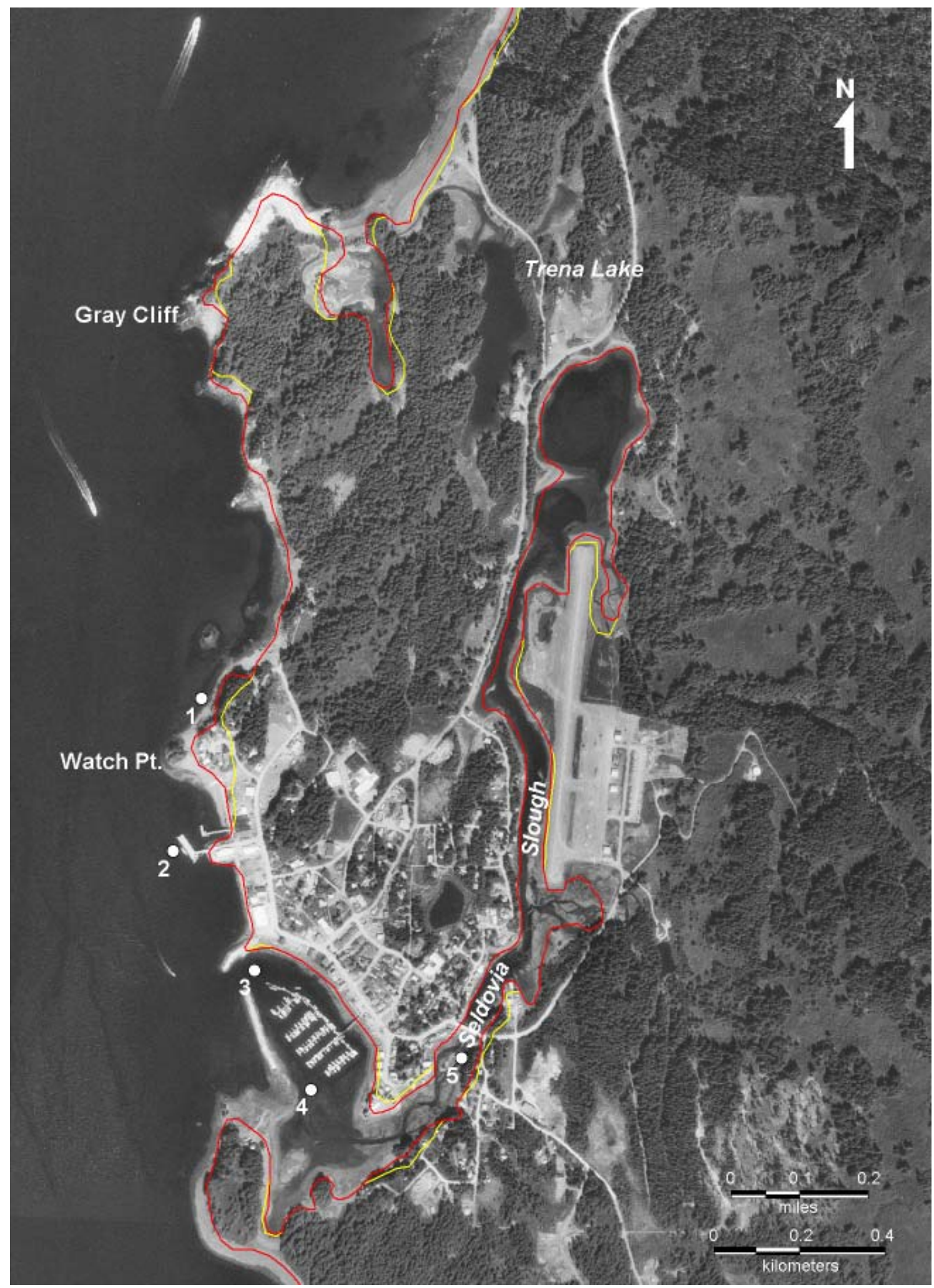

Figure 14. Tsunami inundation scenarios for Seldovia. Red line indicates maximum inundation for a repeat of the 1964 M9.2 earthquake. Yellow line indicates maximum inundation for a hypothetical M7.5 earthquake on the Border Ranges fault. Where no yellow line is visible, it is coincident with the red line. Numbered dots are locations of timehistory measurements for figures 18 and 19. 


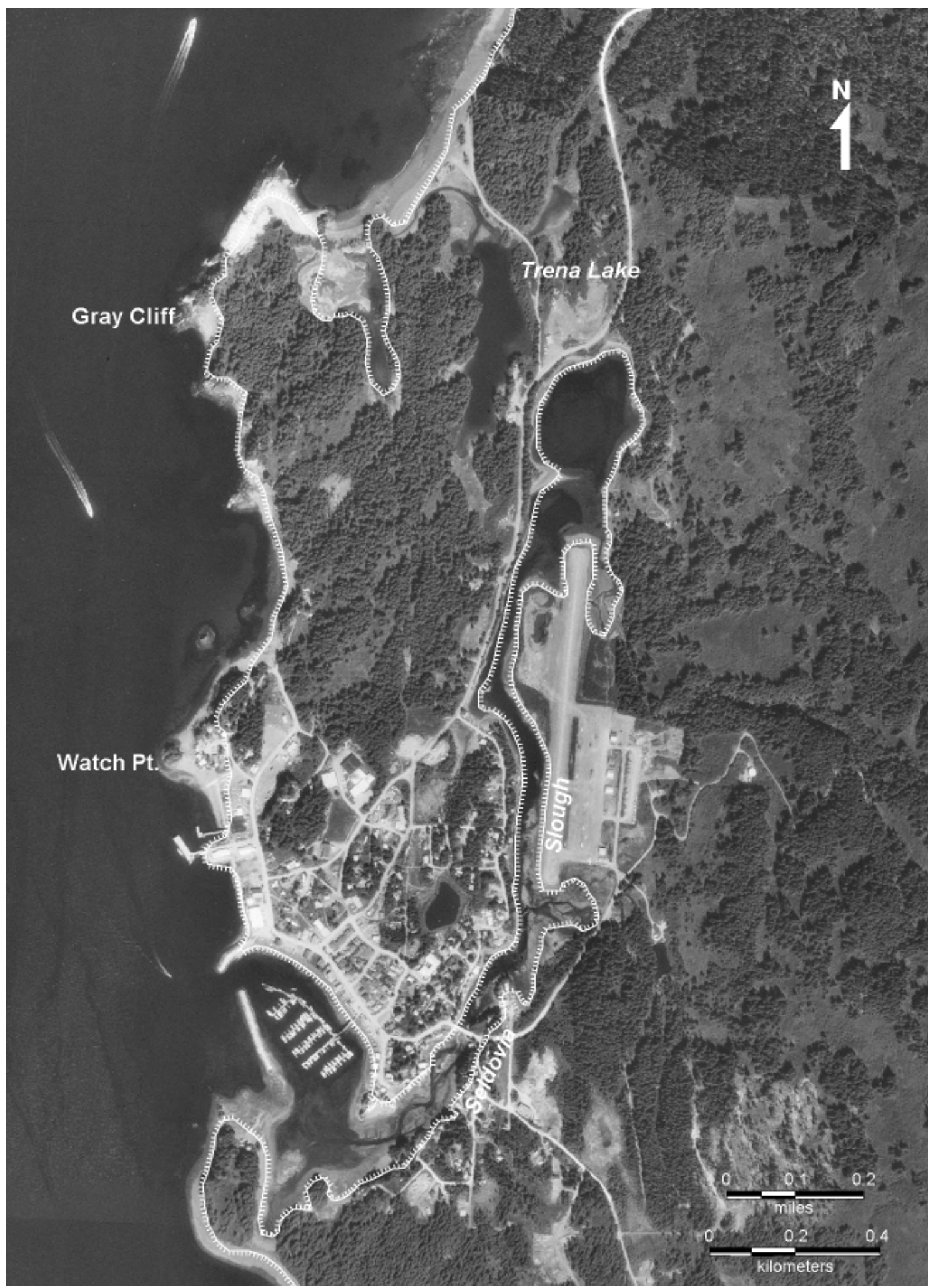

Figure 15. Tsunami hazard map of Seldovia. Hachured line indicates maximum estimated tsunami inundation based on both scenarios depicted in figure 14. Hachures are on water side of line. 
corresponds to the post-earthquake MHHW level. Figure 16 shows change in sea level at six locations offshore the Homer Spit for the modeled 1964 event and for the Border Ranges fault scenario. The computed velocity time histories for the same locations are shown in figure 17. The Border Ranges fault scenario produces, on average, greater amplitudes and velocities in Homer than the 1964 tsunami scenario. The velocity plots demonstrate that current speed could be relatively high and change rapidly. The sea level and velocity time histories at Seldovia locations are represented in figures 18 and 19, respectively. Both Homer and Seldovia time series for the 1964 scenario show wave action within minutes after the earthquake. These waves could not have originated near the epicenter, which was approximately 260 km (160 mi) away. This result agrees with observations of waves in Cook Inlet and Kachemak Bay that were seen by several observers within 5-10 minutes after the quake (Waller, 1966). These seiche waves probably were generated by tectonic subsidence of Kachemak Bay.

The tsunami generated by the 1964 earthquake was recorded on a number of tide gauges around the Pacific Ocean. Many of these records are from Spaeth and Berkman (1972). Also, Lander (1996) gives marigrams from Alaska tide stations for the 1964 tsunami event. Wilson and Torum (1968) constructed the hypothetical marigrams based on eyewitness observations for several locations along the affected coastline.

\section{SOURCES OF ERROR}

The source mechanism remains the biggest unknown in the problem of tsunami modeling. Since the initial condition for the modeling is determined by the displacement of the ocean bottom, the largest source of errors is the earthquake model. When the tsunami is generated in the vicinity of the coast, the direction of the incoming waves, their amplitudes, and times of arrival are determined by the initial displacements of the ocean surface in the source area, because the distance to the shore is too small for the waves to disperse. Therefore, the nearfield inundation modeling results are especially sensitive to the fine structure of the tsunami source. It is much easier to introduce errors in the modeling process when the complexity of the source function is combined with the proximity of the coastal zone.

Another source of error is bathymetric and topographic data used in the model. High-resolution and up-to-date bathymetric data are not available for Homer and Seldovia, as well as for many other Alaska communities. The source for Homer topography was the high-resolution digital elevation model (DEM) derived from LIDAR measurements taken in 2002. This highquality data set does not include Seldovia area. The topographic data used for Seldovia modeling are the nonstandard 10-meter DEMs that were derived by digitizing the existing USGS map products. Data points that fall between elevation contours are interpolated using different algorithms. As a result, the elevation data points that are closer to the contour lines have higher level of vertical accuracy, with the points in the middle having the lowest accuracy of half the contour interval. Unfortunately, we were not able to acquire digital topographic data for Seldovia of a higher level of resolution and accuracy. On the other hand, in order to take advantage of higher resolution topographic data, we would need to splice them with the bathymetric data of the same level of resolution and accuracy. That imposes a limit on the quality of the combined data set, because a new bathymetric survey must be completed in order to substantially improve the resolution of bathymetric data.

The resolution of the grids that are used for inundation modeling is $15.7 \mathrm{~m}$ by $30.8 \mathrm{~m}$ (at 59³5' latitude). It is limited by the resolution of the topographic and bathymetric data used for the grid construction. This resolution is high enough to describe major relief features, although there are some important structures that cannot be resolved by this grid. For example, we modeled breakwaters as artificial walls between two adjacent grid points. Obviously, buildings and other facilities also cannot be accurately resolved by the existing model.

Myers (1998) has shown that the effect of grid refinement leads to energy loss in numerically propagated waves. To test the energy conservation properties of the numerical algorithm, we replaced the open boundaries of the 2-minute grid that covers the Gulf of Alaska with closed land boundaries. This way, energy generated by the initial disturbance of the ocean surface ideally cannot radiate out of the domain and will be conserved. Since the closed land boundaries are not totally reflective, small energy leaks are expected in the system. At every grid point, we calculated the total energy of the water column, and integrated over the entire domain. After 5 hours of tsunami propagation, the energy conservation error remained within 6 percent. When the major tectonic wave reaches Kachemak Bay in about 2 hours after the earthquake, the energy loss is within 3 percent. Myers (1998) also points out that other factors contribute to energy loss in numerical models, such as shallow water assumptions, selection of numerical parameters, and truncation errors.

\section{SUMMARY}

We present the results of numerical modeling of tsunami waves for the Kachemak Bay communities of Homer and Seldovia. We considered two earthquake scenarios and provided an estimate of maximum credible tsunami 

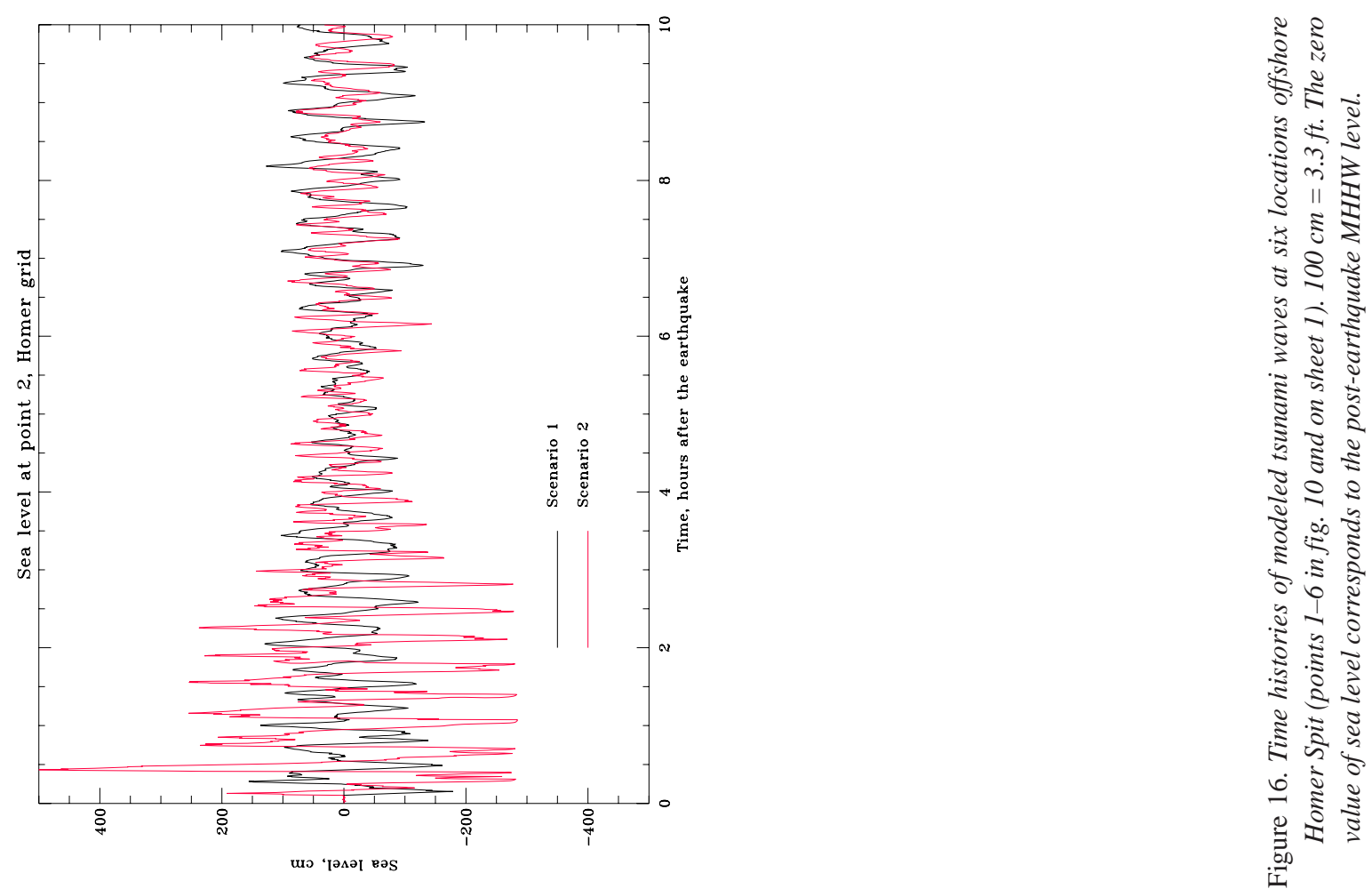

N
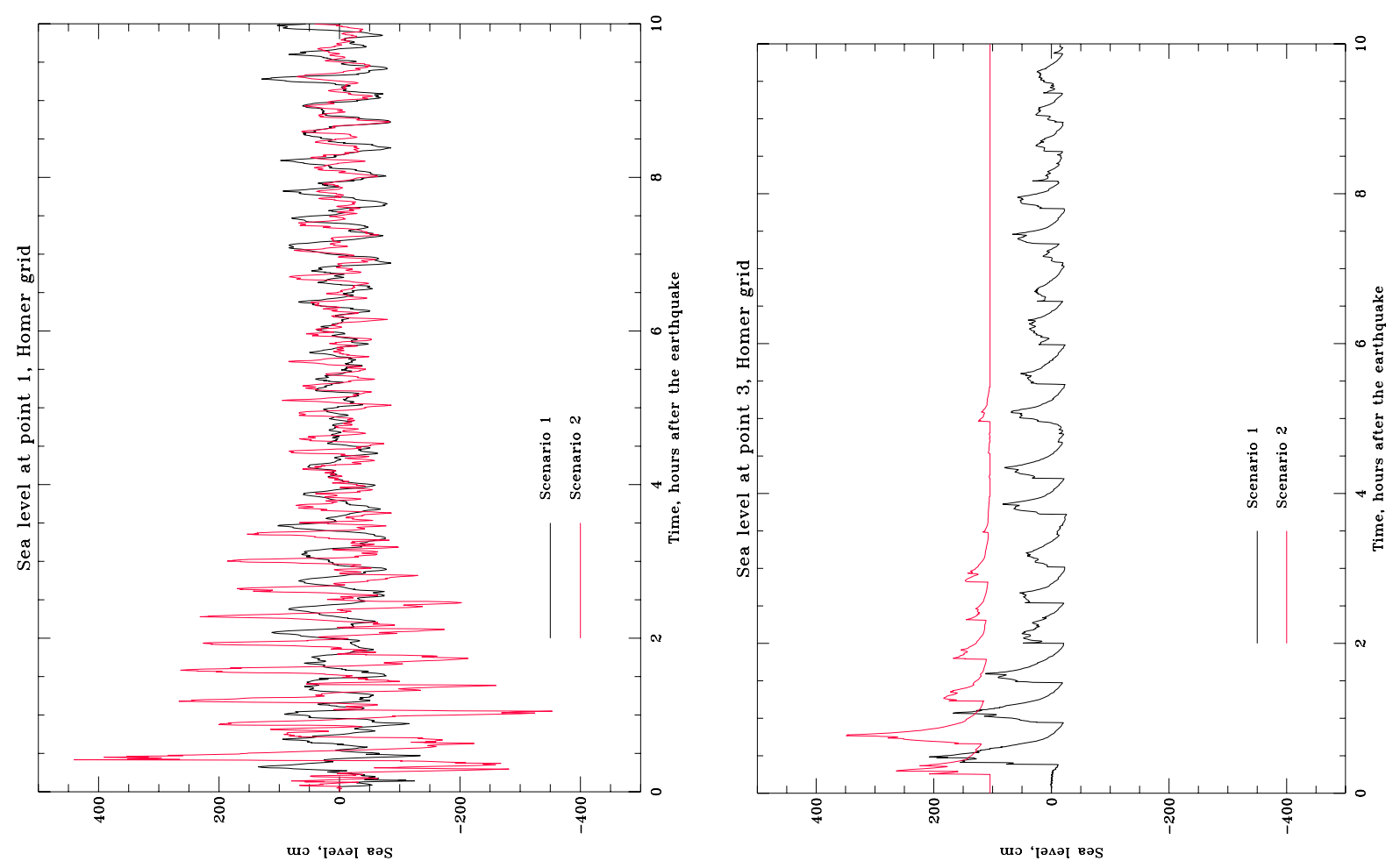

m 

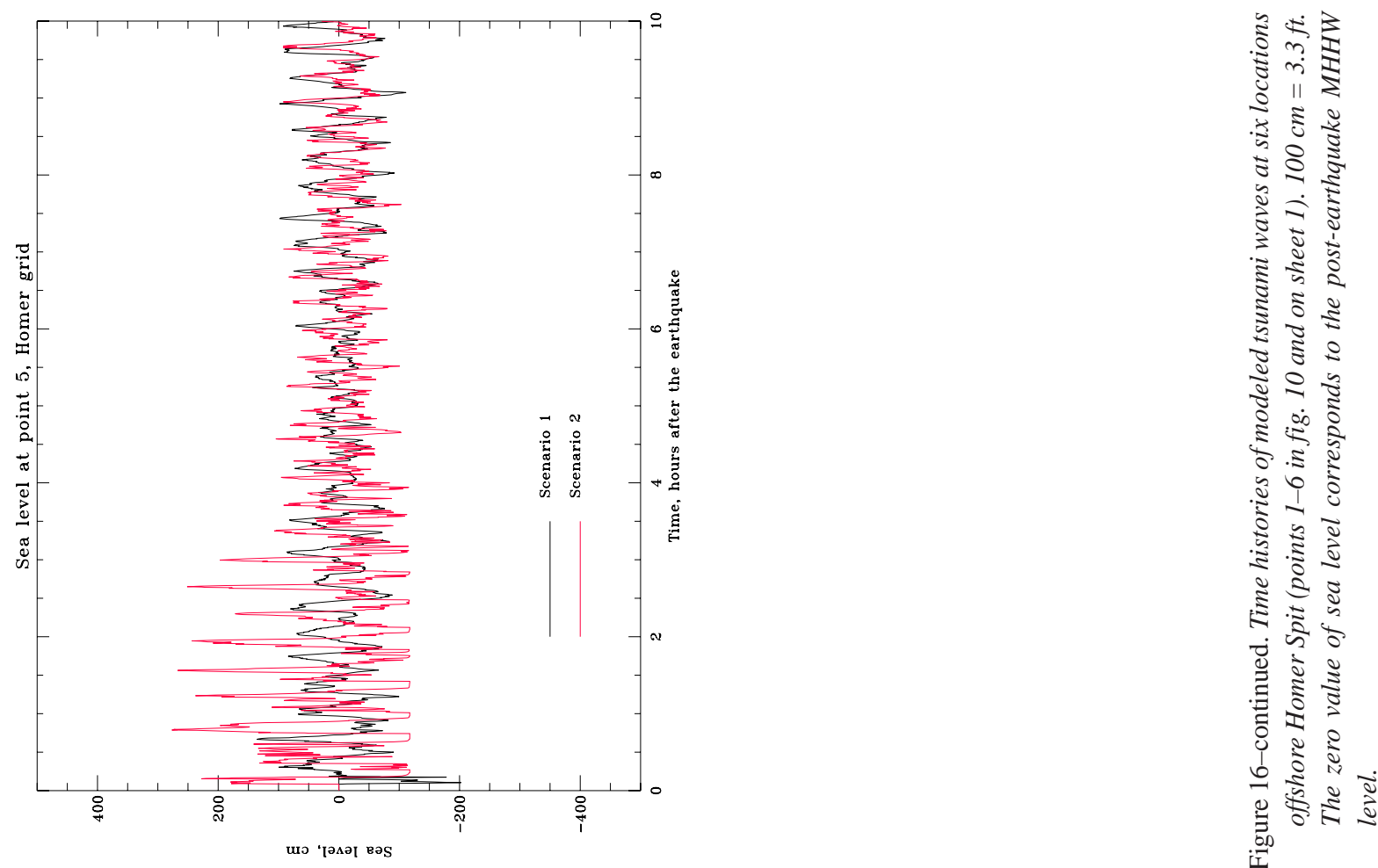

ก
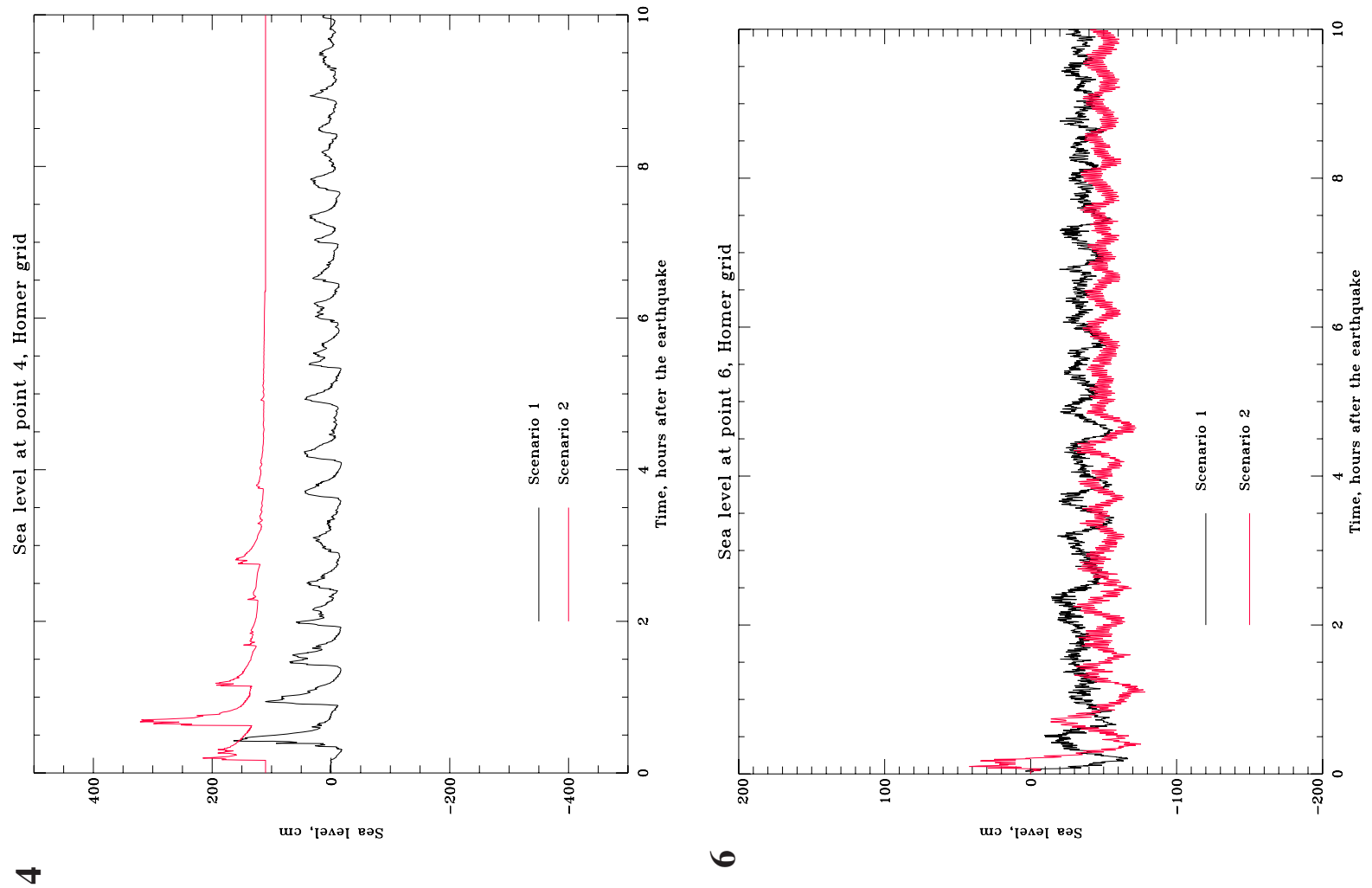


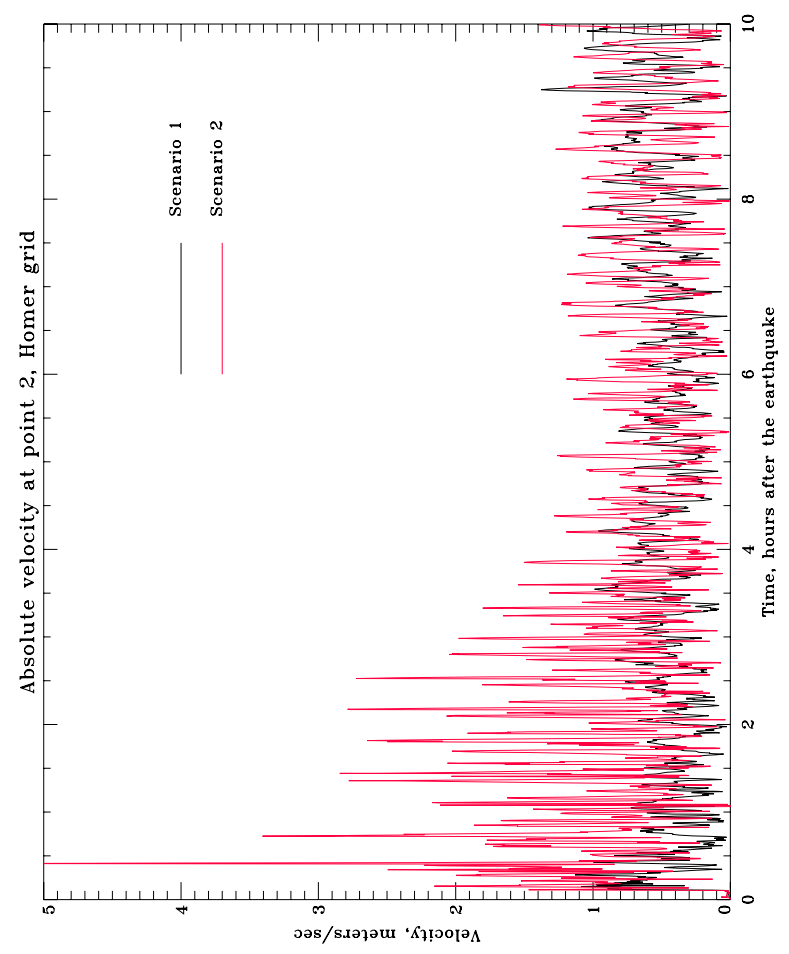

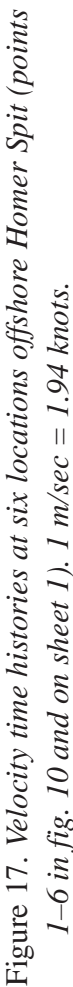

N
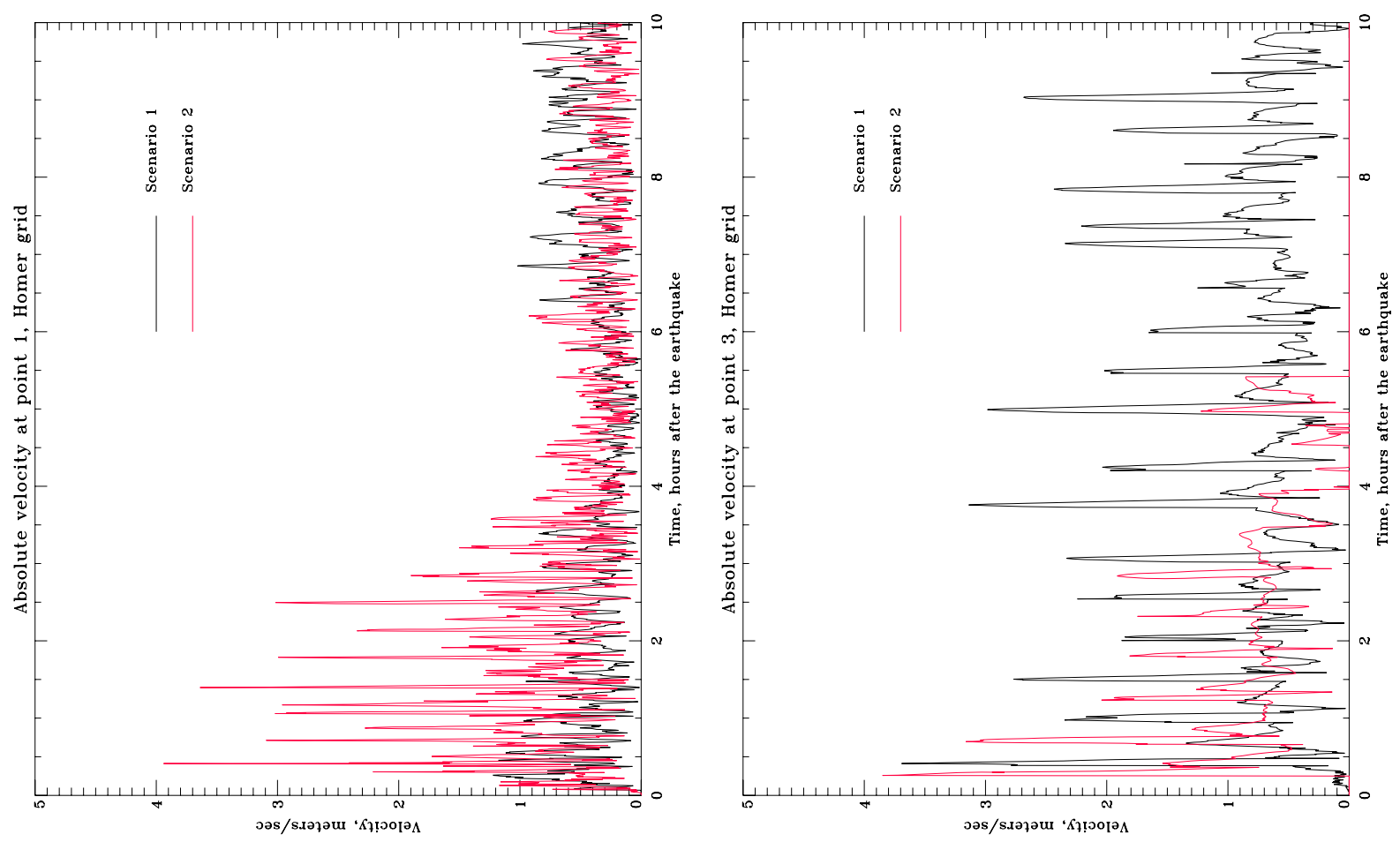

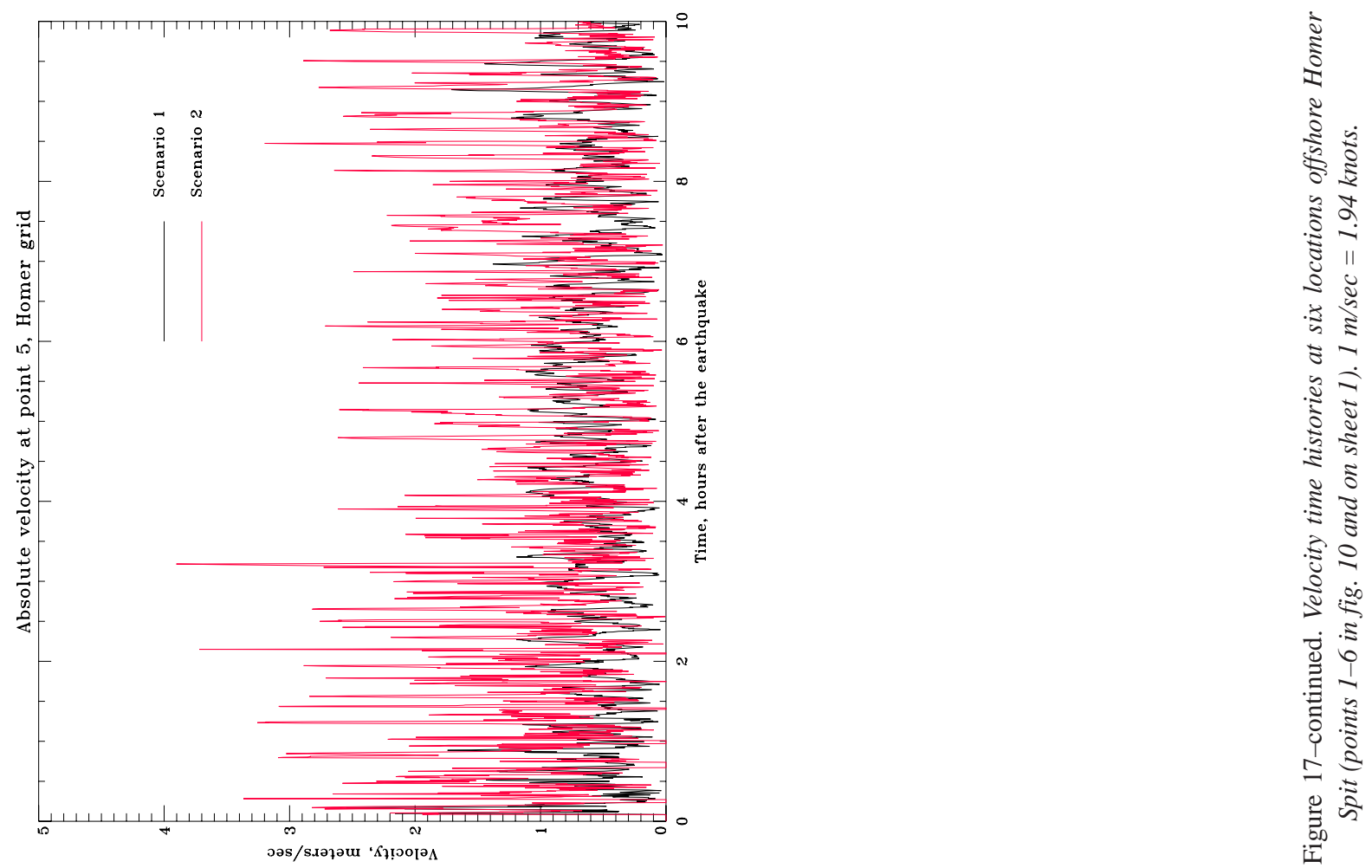

1
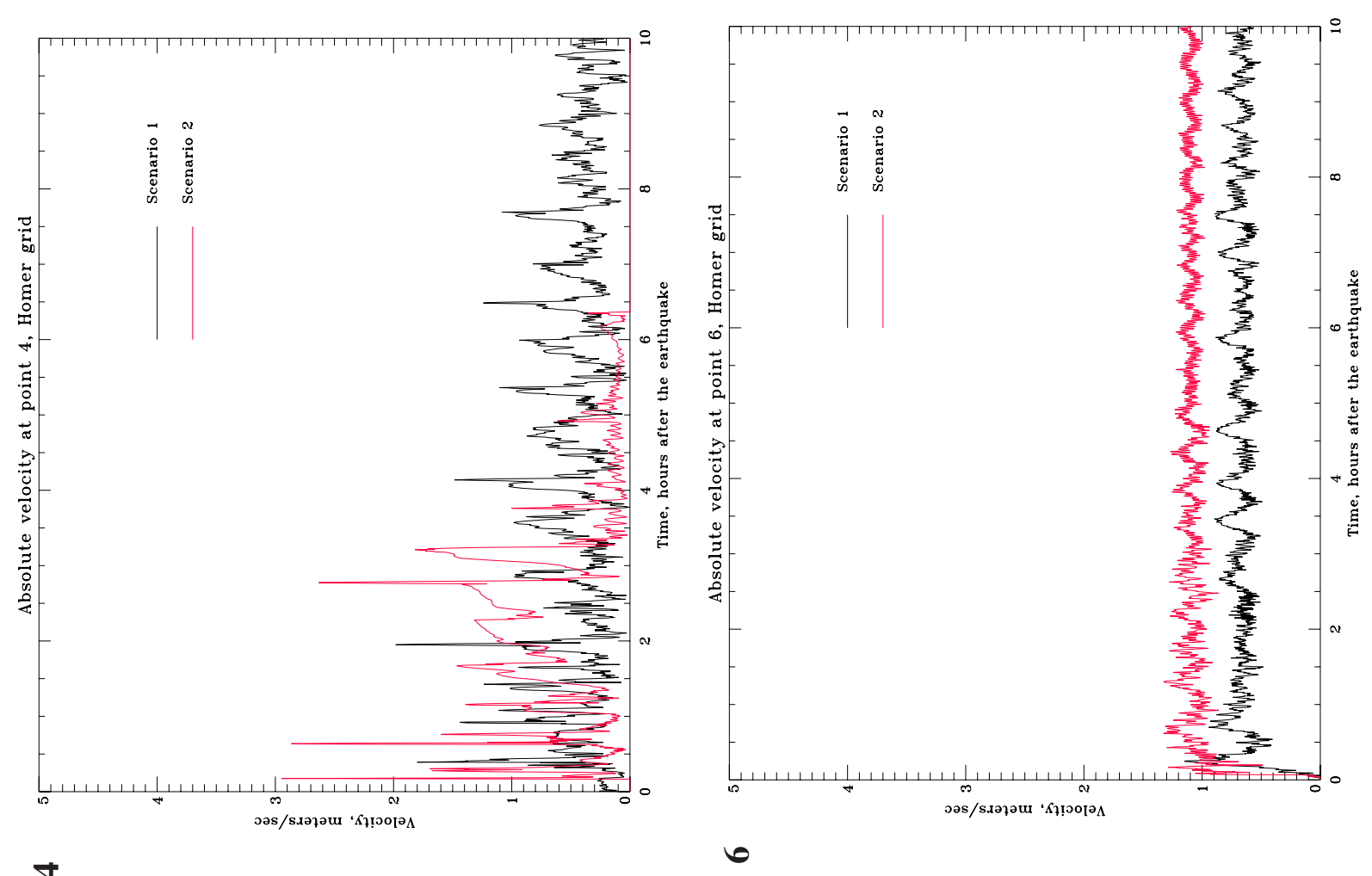

$\checkmark$ 

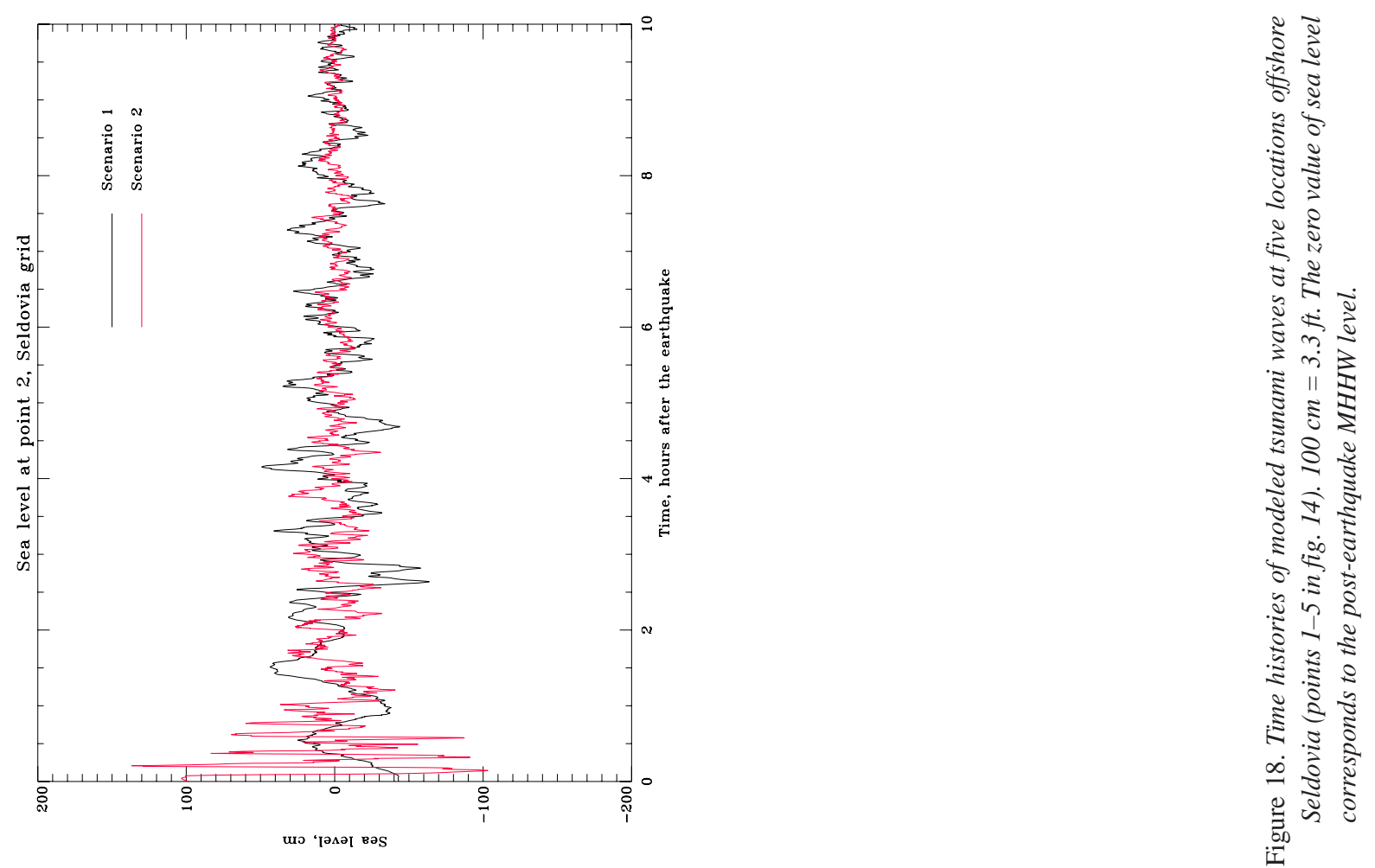

N
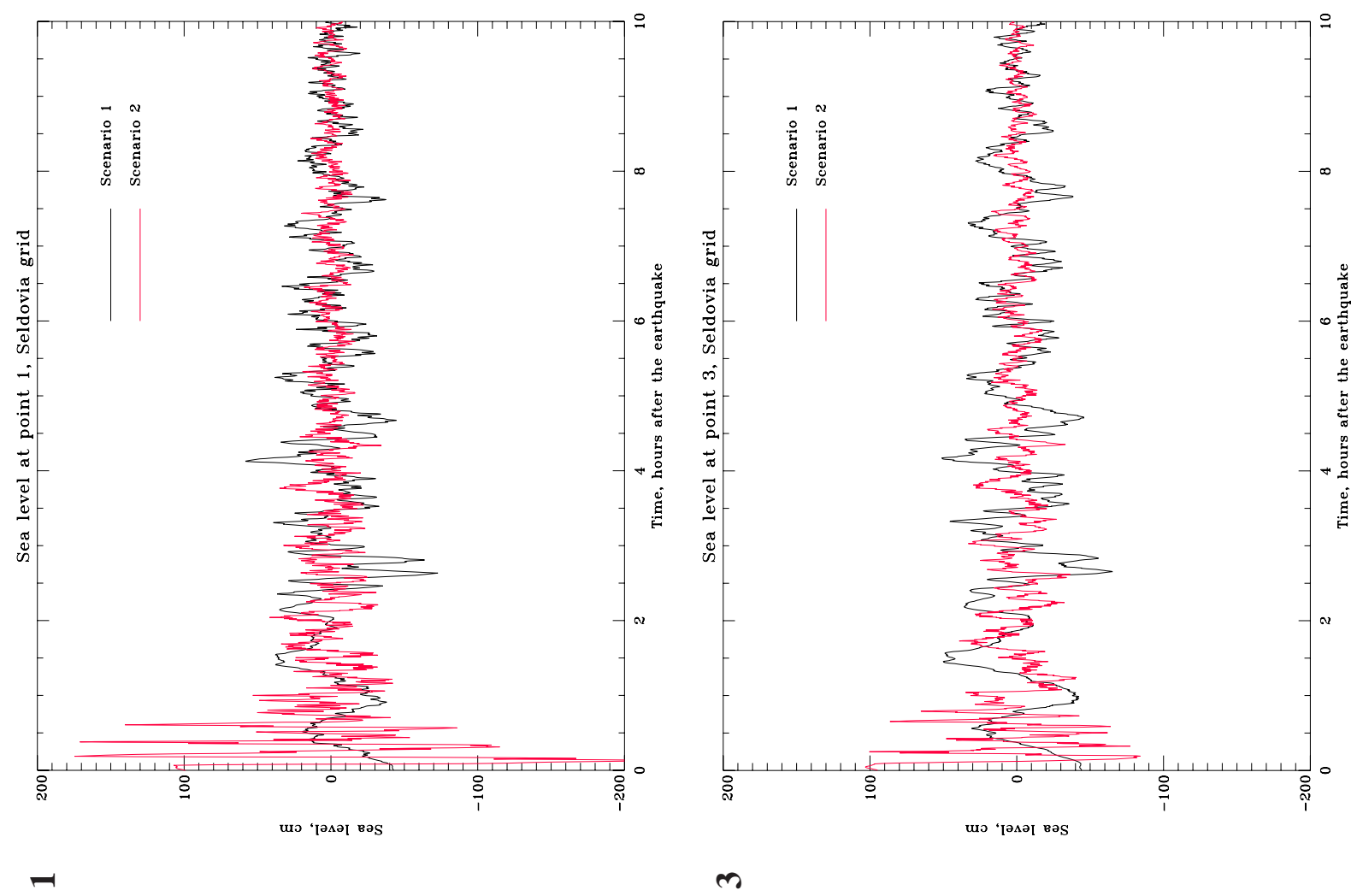
Report of Investigations 2005-2

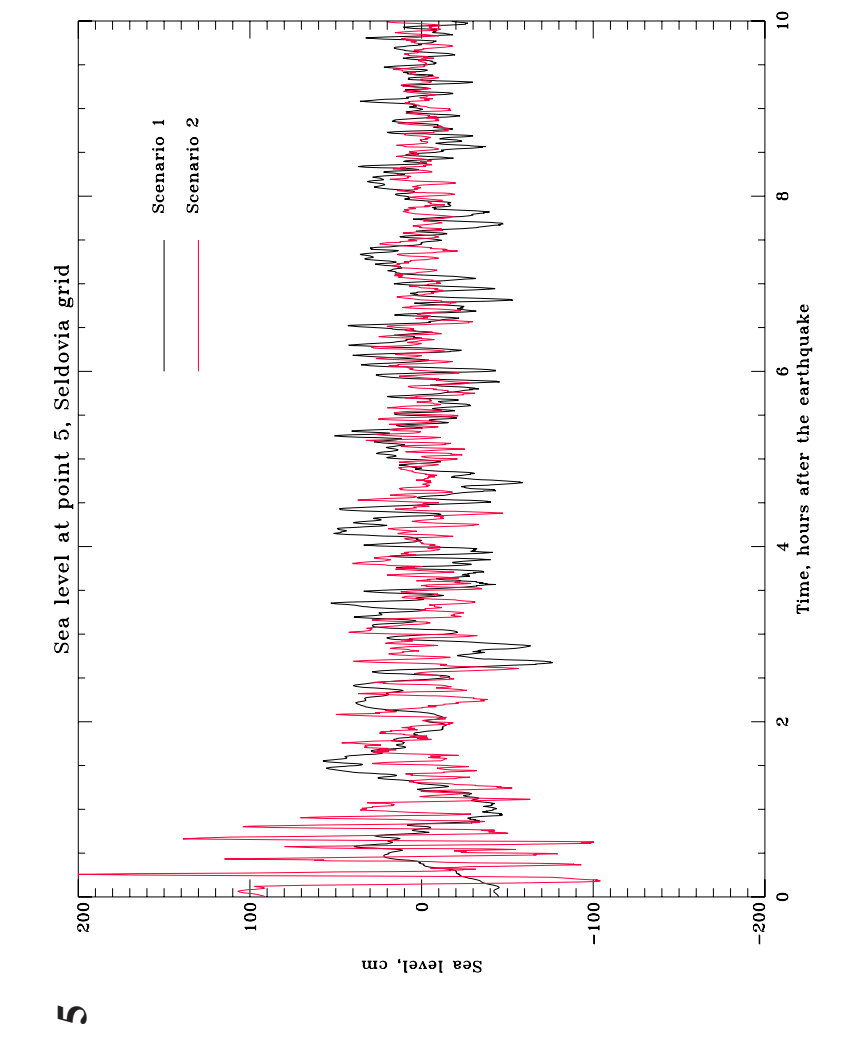

2

(2)

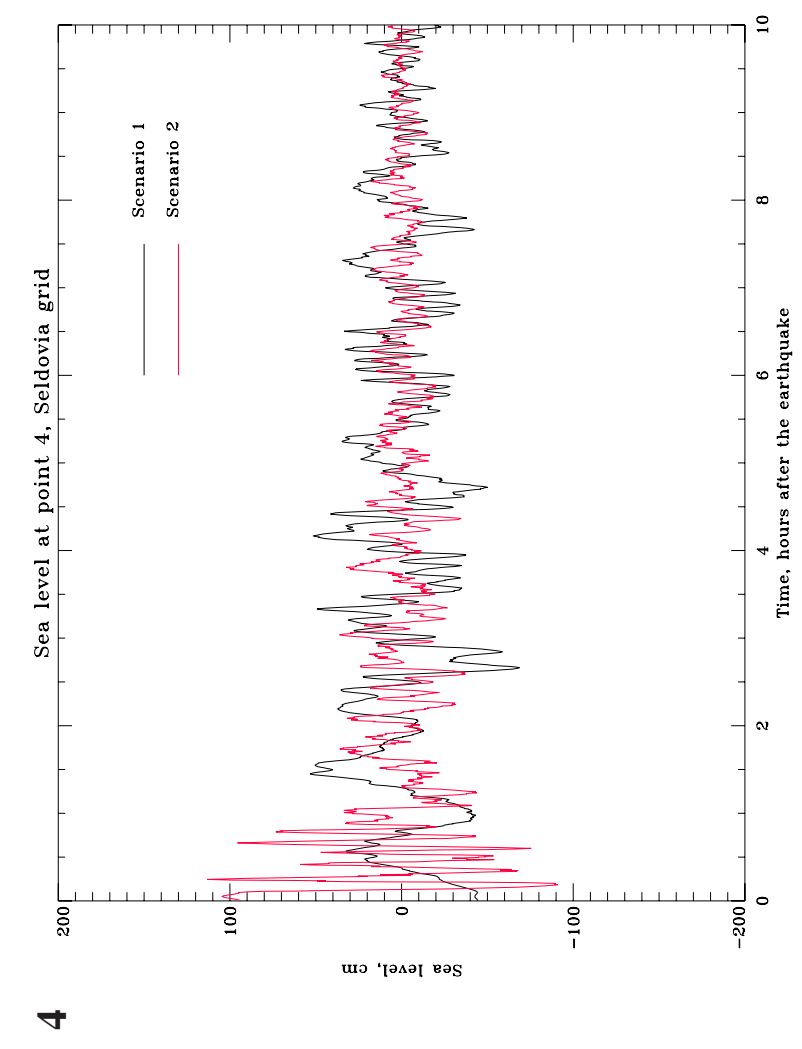

$\frac{\frac{0}{2}}{\frac{2}{2}}$

$\stackrel{2}{2}$

ip

है

$\frac{2}{\frac{8}{2}}$

है

$m$

ธ

$\stackrel{8}{-1}$

કิ 

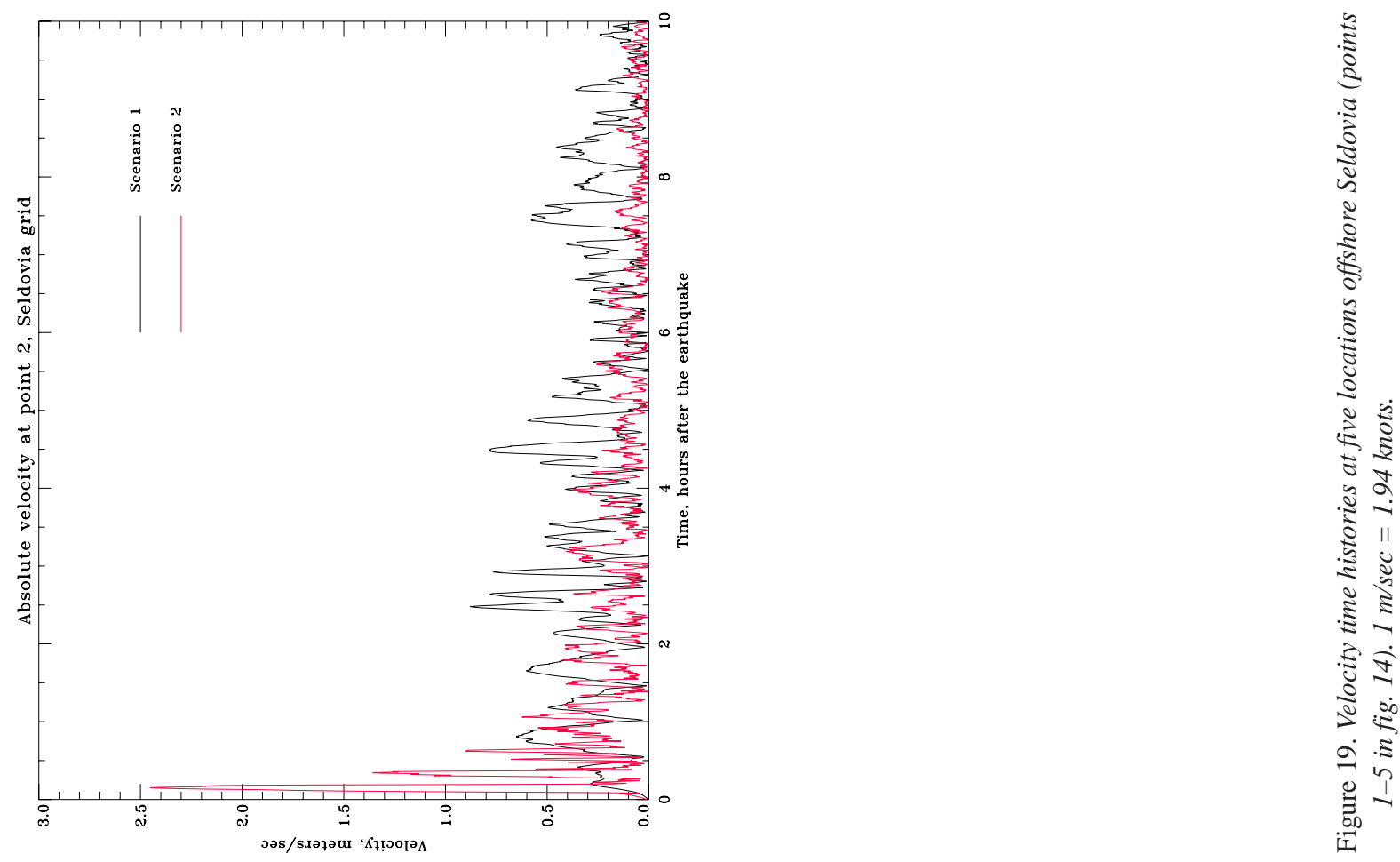

N
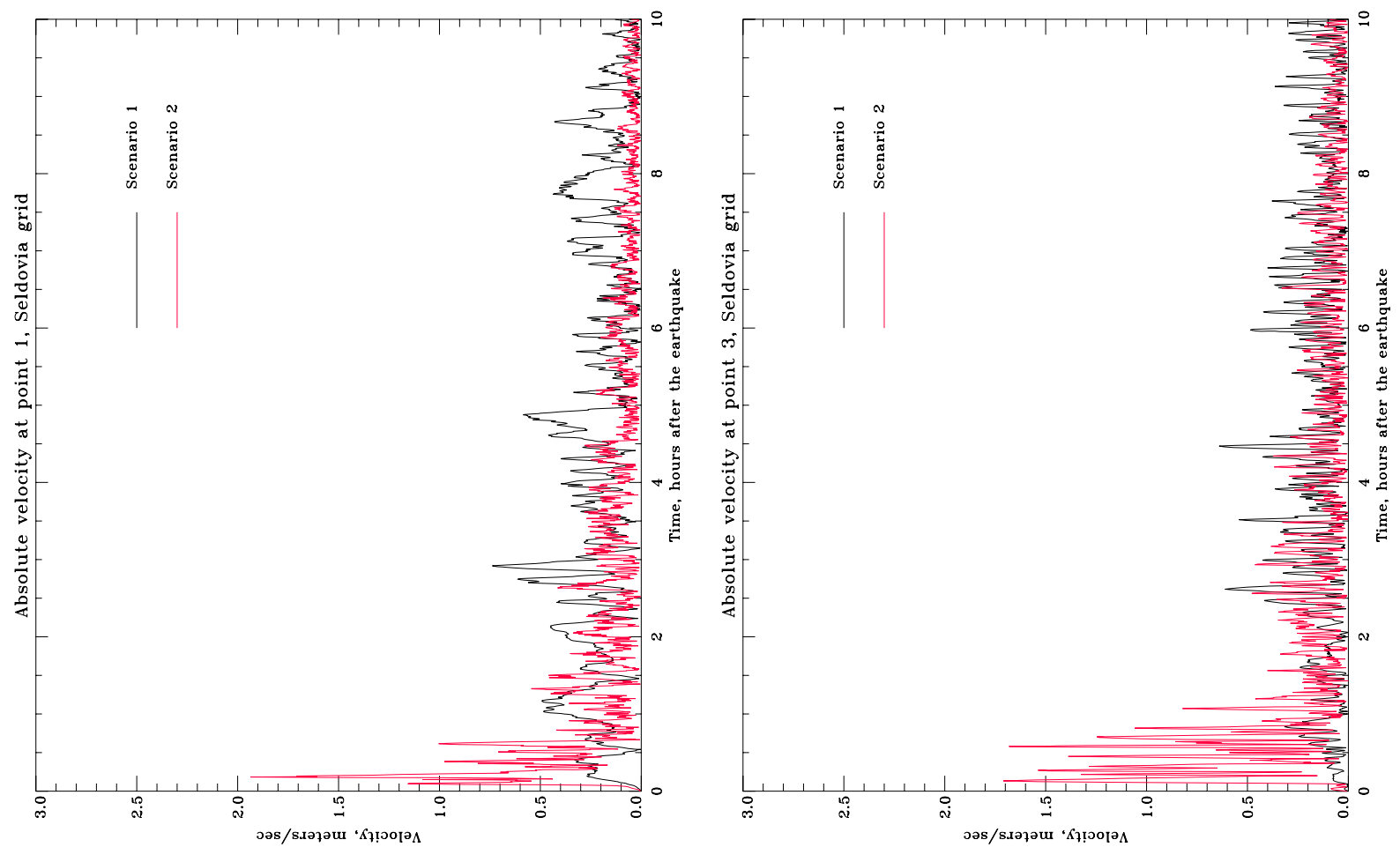
Report of Investigations 2005-2

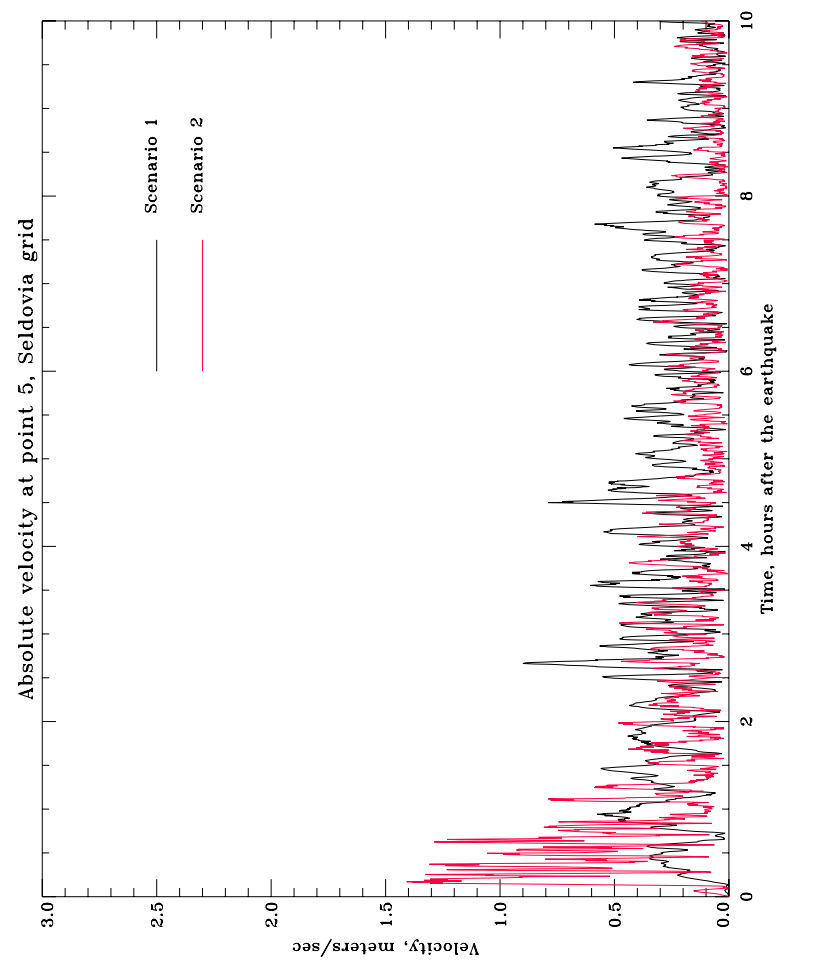

เ

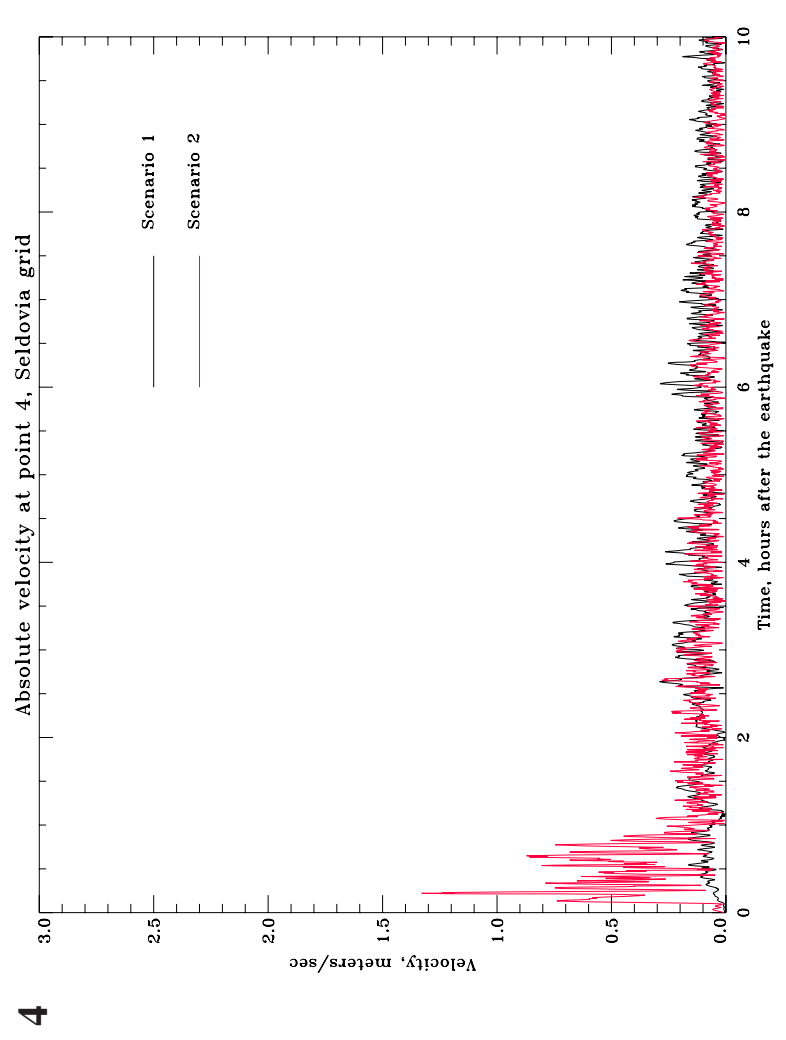


inundation. We did not model as part of this study the inundation by waves that might be generated by local submarine or subaerial landslides, nor did we model inundation from a debris avalanche generated by eruption of nearby Augustine Volcano.

Neither of the modeled scenarios results in inundation of the entire Homer Spit. However, it is important to note that the Border Ranges fault scenario results in flooding of a portion of the spit and the road for a distance of approximately $0.3 \mathrm{mi}(0.5 \mathrm{~km})$ near the head of the spit. Because this flooding may occur repeatedly during a tsunami, it is possible that the road may be washed out, cutting off the evacuation route from the spit. Even though our numerical modeling does not show inundation of the entire spit for the scenarios we used, we recommend that evacuation of the spit be a mandatory part of any tsunami evacuation plan.

These results are useful for state and local emergency managers to identify areas that should be evacuated in the event of a major tsunamigenic earthquake. Because of the uncertainties inherent in this type of modeling, these results are not intended for land-use regulation.

\section{ACKNOWLEDGMENTS}

This project was supported by the National Oceanic and Atmospheric Administration, National Tsunami Hazard Mitigation Program, through grant NA17RJ1224. The authors wish to thank Dr. Fumihiko Imamura for the Fortran code of the Okada algorithm he kindly provided. We also thank Dr. George R. Priest and Dr. Jose Borrero for their thoughtful reviews of the draft manuscript and maps, and Dr. Natalia Ratchkovsky for the review of the seismicity analysis.

Data used for the bathymetric and topographic grids are credited to the following sources:

National Oceanic and Atmospheric Administration, National Geodetic Database Centers. Hydrographic Surveys and Marine Geophysics Tracklines, GEODAS Version 4.0 Software. Boulder, Colorado. Website reference:

http://www.ngdc.noaa.gov/mgg/bathymetry/ relief.html.

U.S. Geological Survey, National Mapping Division. Topographic Digital Elevation Models and Digital Raster Graphics. Reston, Virginia. Website reference: http://mapping.usgs.gov/.

U.S. Army Corps of Engineers - Alaska District. Hydrographic Surveys for Homer and Seldovia. Anchorage, Alaska. Website reference: http://www.poa.usace.army.mil/.

Walker and Associates, Inc. Analog Photogrammetry of Homer. Homer, Alaska. Website reference: http://publicworks.ci.homer.ak.us/.
Aeromap, U.S. Homer LIDAR Grid, used with permission. Anchorage, Alaska. Website reference: http://www.aeromap.com/.

\section{REFERENCES CITED}

Bradley, D.C., Kusky, T.M., Haeussler, P.J., Karl, S.M., and Donley, D.T., 1999, Geologic map of the Seldovia quadrangle, south-central Alaska: U.S. Geological Survey Open-File Report 99-18, http:// wrgis.wr.usgs.gov/open-file/of99-18.

Christensen, D.H., and Beck, S.L., 1994, The rupture process and tectonic implications of the Great 1964 Prince William Sound earthquake: Pageoph, v. 142, no. 1, p. 29-53.

Combellick, R.A., 1997, Evidence of prehistoric great earthquakes in the Cook Inlet region, Alaska, in Karl, S.M., Vaughn, N.R., and Ryherd, T.J., eds., Guide to the Geology of the Kenai Peninsula, Alaska: Anchorage, Alaska Geological Society, 128 p.

DeMets, C., Gordon, R.C., Argus, D.F., and Stein, S., 1990, Current plate motions: Geophysical Journal International, v. 101, p. 425-478.

Doser, D.I., and Brown, W.A., 2001, A study of historic earthquakes of the Prince William Sound, Alaska, Region: Bulletin of the Seismological Society of America, v. 91, p. 842-857.

Doser, D.I., Ratchkovski, N.A., Haeussler, P.J., and Saltus, R., 2004, Changes in crustal seismic deformation rates associated with the 1964 Great Alaska Earthquake: Bulletin of the Seismological Society of America, v. 94, no. 1, p. 320-325.

Freymueller, J.T., Cohen, S.C., and Fletcher, H.J., 2000, Spatial variations in present-day deformation, Kenai Peninsula, Alaska, and their implications: Journal of Geophysical Research, v. 105, no. B4, p. 80798101.

Haeussler, P.J., and Saltus R.J., in review, Location and extent of Tertiary structures in Cook Inlet basin, Alaska: U.S. Geological Survey Scientific Investigations Report.

Johnson, J.M., Satake, K., Holdahl, S.R., and Sauber, J., 1996, The 1964 Prince William Sound earthquake: Joint inversion of tsunami waveforms and geodetic data: Journal of Geophysical Research, v. 101, no. B1, p. 523-532.

Kachadoorian, R., and Plafker, G., 1967, Effects of the earthquake of March 27, 1964 on the communities of Kodiak and nearby islands: U.S. Geological Survey Professional Paper 542-F, 41 p.

Kowalik, Z., and Murty, T.S., 1993, Numerical simulation of two-dimensional tsunami runup: Marine Geodesy, v. 16, p. 87-100.

Lander, J.F., 1996, Tsunamis affecting Alaska, 17371996: National Geophysical Data Center (NGDC): 
Key to Geophysical Research Documentation, no. 31, 195 p.

MacKevett, E.M., Jr., and Plafker, G., 1974, The Border Ranges fault in south-central Alaska: Journal of Research of the US Geological Survey, v. 2, no. 3, p. 323-329.

Murty, T.S., 1984, Storm surges-Meteorological ocean tides: Canadian Bulletin of Fisheries and Aquatic Sciences, v. 212, 897 p.

Myers, E.P., 1998, Physical and numerical analysis of long wave modeling for tsunamis and tides: Portland, Oregon, Oregon Health \& Science University, Oregon Graduate Institute of Science and Technology, Ph.D. thesis, 289 p.

Okada, Y., 1985, Surface deformation due to shear and tensile faults in a half-space: Bulletin of the Seismological Society of America, v. 75, p. 1135-1154.

Page, R.A., Biswas, N.N., Lahr, J.C., and Pulpan, H., 1991, Seismicity of continental Alaska: in Slemmons, D.B., Engdahl, E.R., Soback, M.D., and Blackwell, D.D., eds., Neotectionics of North America: Boulder, Colorado, Geological Society of America, Decade Map Volume 1.

Plafker, G., Carver, G.A., and Clarke, S.H., Jr., 2000, Seismotectonics of the 1964 Alaska earthquake as an analog for future tsunamigenic southern Cascadia subduction earthquakes, in Clague, J., Atwater, B., Wang, K., Wang, M.M., and Wong, I., eds., Proceedings of the Geological Society of America Penrose Conference, Great Cascadia Earthquake Tricentennial: Oregon Department of Geology and Mineral Industries Special Paper 33, p. 96-97.
Reid, R.O., and Bodine, B.R., 1968, Numerical model for storm surges in Galveston Bay: Journal of the Waterways and Harbors Division, v. 94, no. WWI, p. 33-57.

Spaeth, M.G., and Berkman, S.C., 1972, Tsunami of March 28, 1964, as recorded at tide stations and the Seismic Sea Waves Warning System, in The Great Alaska Earthquake of 1964, oceanography and coastal engineering: Washington, D.C., National Academy of Sciences, p. 38-100.

Suleimani, E.N., Hansen, R.A., Combellick, R.A., Carver, G.A., Kamphaus, R.A., Newman, J.C., and Venturato, A.J., 2002, Tsunami hazard maps of the Kodiak area, Alaska: Alaska Division of Geological \& Geophysical Surveys Report of Investigation 2002-1, 16 p.

Troshina, E.N., 1996, Tsunami waves generated by Mt. St. Augustine volcano, Alaska: University of Alaska Fairbanks, M.S. thesis, 84 p.

Waller, R.M., 1966, Effects of the earthquake of March 27, 1964 in the Homer area, Alaska: U.S. Geological Survey Professional Paper 542-D, 28 p.

Waythomas, C.F., 2000, Reevaluation of tsunami formation by debris avalanche at Augustine Volcano, Alaska, in Keating, B.H., Waythomas, C.F., and Dawson, A.G., eds., Landslides and Tsunamis: Basel, Switzerland, Birkhaeuser Verlag, Pure and Applied Geophysics, v. 157, no. 6-8, p. 1145-1188.

Wilson, B.W., and Torum, A., 1968, The tsunami of the Alaskan Earthquake, 1964: Engineering evaluation: U.S. Army Corps of Engineers, Technical memorandum No. 25, 401 p. 


\section{Appendix I \\ Vertical Datum Conversions for Homer and Seldovia, Alaska}

The following table provides a listing of the available benchmarks in the Homer and Seldovia area that have been referenced to one or more datums by the National Geodetic Survey (NGS) and the Center for Operational Oceanographic Products and Services (CO-OPS). This information was used to convert various data sources to a single vertical datum for grid computation and was gathered from the NGS and CO-OPS websites: http:// www.ngs.noaa.gov/ and http://www.co-ops.nos.noaa.gov/.

\section{5-5500 Seldovia, Cook Inlet, AK}

$5926.4^{\prime} \mathrm{N}, 15143.2^{\prime} \mathrm{W}$

NOAA Chart: 16646

USGS Quad: Seldovia B-5

Publication Date: 11/02/99
Tidal datum of Seldovia, Cook Inlet based on:

Length of Series: 5 yr

Time Period: January 1994-1998

Tidal Epoch: 1960-1978

Control Tide Station: SELDOVIA

\begin{tabular}{|c|c|c|c|c|c|c|}
\hline \multirow{2}{*}{\multicolumn{3}{|c|}{ CO-OPS Benchmarks }} & \multirow[t]{2}{*}{ PID\# } & \multirow[t]{2}{*}{ Benchmark } & \multicolumn{2}{|c|}{ in meters above: } \\
\hline & & & & & MLLW & MHW \\
\hline HOWL (10/15/1966) & 7.647 & \multirow[t]{10}{*}{ meters } & & BM 191967 & 9.043 & 3.807 \\
\hline MHHW & 5.480 & & & NO 131964 & 8.209 & 2.973 \\
\hline MHW & 5.236 & & & NO 201968 & 9.012 & 3.776 \\
\hline MSL & 2.899 & & & PM-2 1967 & 8.942 & 3.706 \\
\hline MTL & 2.874 & & & TIDAL BM 30 & 10.011 & 4.775 \\
\hline MLW & 0.512 & & & 5500 A 1982 & 11.109 & 5.873 \\
\hline MLLW & 0.000 & & & 5500 В 1982 & 11.113 & 5.877 \\
\hline \multirow[t]{3}{*}{ LOWL (01/29/1979) } & -1.830 & & & 5500 C 1982 & 9.620 & 4.384 \\
\hline & & & & 5500 D 1982 & 9.613 & 4.377 \\
\hline & & & & 5500 E 1987 & 8.943 & 3.707 \\
\hline
\end{tabular}

Seldovia tidal datum does not have connection to Geodetic datum

945-5557 Homer, Cook Inlet, AK

$5936.2^{\prime} \mathrm{N}, 15125.2^{\prime} \mathrm{W}$

NOAA Chart: 16640

USGS Quad: Seldovia C-4

Publication Date: 11/01/84
Tidal datum of Homer, Cook Inlet based on:

Length of Series: 2 yr

Time Period: 1966-1967

Tidal Epoch: 1960-1978

Control Tide Station: SELDOVIA (9455500)

\begin{tabular}{|c|c|c|c|c|c|c|}
\hline \multirow{2}{*}{\multicolumn{3}{|c|}{ CO-OPS Benchmarks }} & \multirow{2}{*}{ PID\# } & \multirow{2}{*}{ Benchmark } & \multicolumn{2}{|c|}{ in meters above: } \\
\hline & & & & & MLLW & MHW \\
\hline \multicolumn{7}{|l|}{ HOWL } \\
\hline $\begin{array}{l}\text { (10/15/1966) } \\
\text { MHHW }\end{array}$ & $\begin{array}{l}7.681 \\
5.566\end{array}$ & meters & & $\begin{array}{l}5557 \text { А } 1979 \\
5557 \text { В } 1979\end{array}$ & $\begin{array}{l}7.934 \\
7.964\end{array}$ & $\begin{array}{l}2.618 \\
2.649\end{array}$ \\
\hline MHW & 5.316 & & TT0174 & В 1031965 & 7.934 & 2.618 \\
\hline MTL & 2.905 & & & BM 61965 & 8.056 & 2.740 \\
\hline MLW & 0.497 & & & BM 71973 & 9.565 & 4.249 \\
\hline MLLW & 0.000 & & TT0175 & C 1031965 & 7.952 & 2.637 \\
\hline LOWL & & & & HOMER EAST & & \\
\hline (04/25/1967) & -1.859 & & TT0171 & B & 9.190 & 3.874 \\
\hline
\end{tabular}




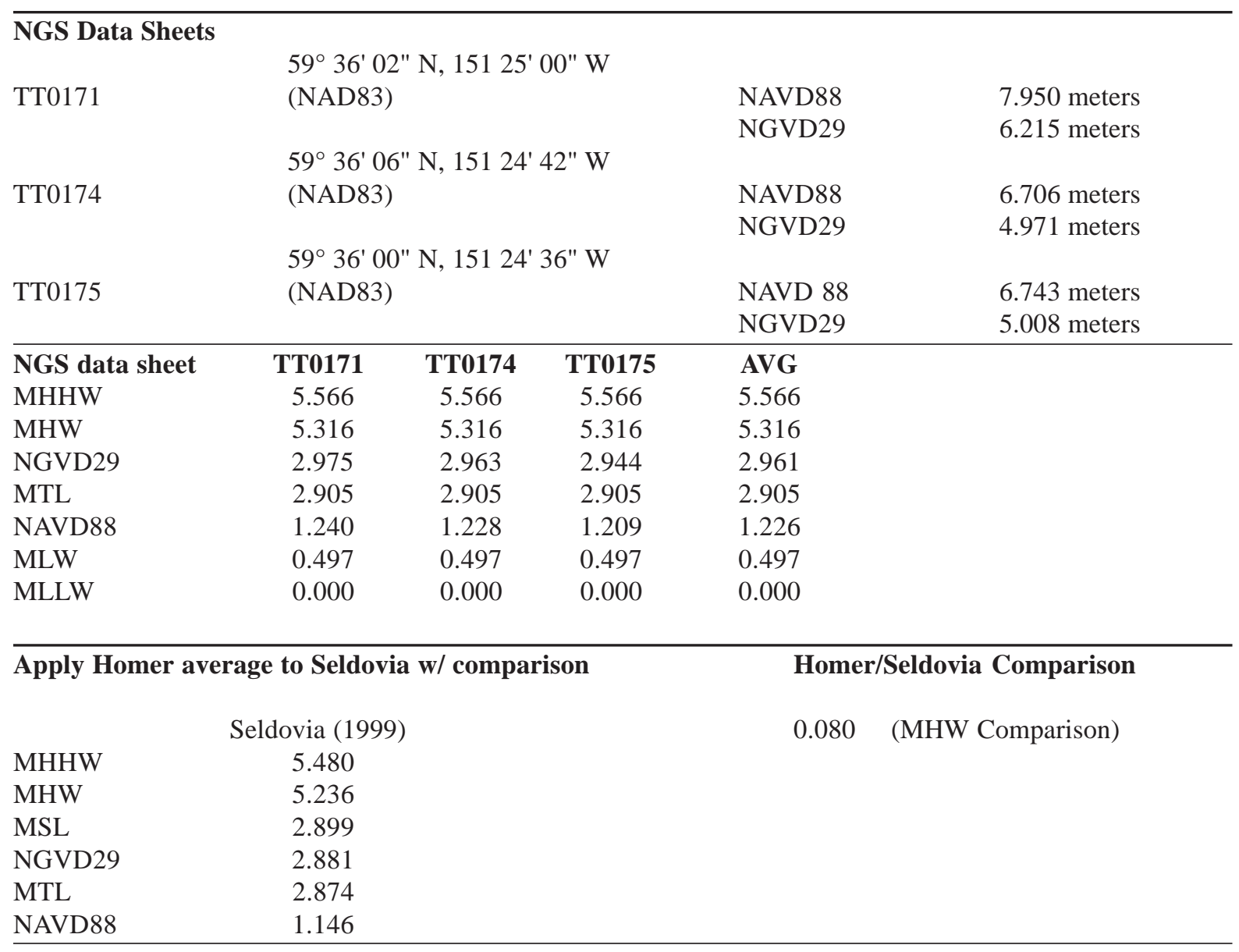


END OF REPORT 